\title{
Ethanol extract of Acanthopanax senticosus (Rupr. \& Maxim.) Harms induces liver cancer cell apoptosis through inhibiting NF-кB
}

\author{
Baolei Zhao", Wentao Zhu ${ }^{1}$, Xinqiang $\mathrm{Han}^{1}$, Xin $\mathrm{Li}^{2}$, Yanmin $\mathrm{Lu}^{1}$, Xuefeng Cao ${ }^{1}$, Fan Zhang ${ }^{1}$, Xutao Lin ${ }^{1}$, \\ Xingyuan Zhang', Qiangpu Chen ${ }^{1}$ \\ ${ }^{1}$ Department of Hepatobiliary Surgery, Binzhou Medical University Hospital, Binzhou 256603, China; ${ }^{2}$ Department of Gynecology, Binzhou \\ People's Hospital, Binzhou 256603, China \\ Contributions: (I) Conception and design: B Zhao, W Zhu; (II) Administrative support: X Han; (III) Provision of study materials: X Li, Y Lu, X Cao; \\ (IV) Collection and assembly of data: F Zhang, X Lin; (V) Data analysis and interpretation: X Zhang, Q Chen; (VI) Manuscript writing: All authors; \\ (VII) Final approval of manuscript: All authors. \\ Correspondence to: Baolei Zhao. Department of Hepatobiliary Surgery, Binzhou Medical University Hospital, No. 661, Huanghe 2nd Road, Binzhou \\ 256603, China. Email: zhao_baolei@126.com.
}

\begin{abstract}
Background: Acanthopanax senticosus (Rupr. \& Maxim.) Harms, a traditional Chinese medicine, has been used to treat various diseases, including ischemic, heart diseases, hepatocellular carcinoma (HCC), hypertension and neurasthenia. The purpose of this study was to investigate the anticancer activity of $A$, senticosus (ASE).

Materials: MTT assay, clonogenicity, reverse transcription-polymerase chain reaction (RT-PCR), flow cytometry and Western blot were employed to evaluate the viability and invasion of liver cancer cells. In addition, luciferase assay was used to delineate the inhibitory activity of ethanol extract against NF- $\kappa \mathrm{B}$.

Results: Our results showed that the ethanol extract of ASE could decrease the viability of cancer cells. In addition, the ethanol extract could decrease the protein levels of Matrix metalloproteinase-2 (MMP-2), MMP-9, t-protein kinase B (Akt) and p-Akt, but increase those of E-cadherin. Nuclear factor kappa beta (NF-kB)-Luciferase assay showed the ethanol extract could effectively inhibit the activity of NF- $\kappa$ B. Furthermore, fourteen compounds including seven active compounds were isolated and activities against $\mathrm{NF}-\mathrm{kB}$ were investigated.
\end{abstract}

Conclusions: This study confirmed that the ASE could be as an alternative or complementary therapy to treat liver cancer.

Keywords: Acanthopanax senticosus (ASE); liver cancer cells; nuclear factor kappa beta (NF-кB); active compounds; apoptosis

Submitted Jul 29, 2019. Accepted for publication Nov 26, 2019.

doi: $10.21037 /$ tcr.2020.01.02

View this article at: http://dx.doi.org/10.21037/tcr.2020.01.02

\section{Introduction}

Cancer, one of the common diseases, leads to high morbidity and mortality worldwide (1). Among lots of cancers, hepatocellular carcinoma (HCC) is a kind of malignancies which induces by some factors, including persistent infection with hepatitis B virus or some food containing nitrosamines and alcohol $(2,3)$. In addition, it also causes huge economic losses to the society. There are some main therapeutic methods for HCC, including surgery, chemotherapy and radiotherapy. However, there are some serious side effects of these methods, including nausea, emesis and physical asthenia, which cannot be ignored and some patients cannot afford the high medical expenses (4). Therefore, efforts to seek the alternative and effective therapies for HCC need to be intensified.

The Acanthopanax senticosus (Rupr. \& Maxim.) Harms, also known as edible tonic in China, is a shrub which widely distributes in Northeast Asia and Siberia. It possesses a wide range of active compounds, such as diterpenoids, triterpenoids, lignans and phenylpropanoids $(5,6)$. In addition, it has been traditionally used as a folk medicine 
for treating rheumatism, diabetes and hepatitis $(7,8)$. More interesting, this plant is used in some parts of Northern China as an ethnomedicine against tumor, and some studies have confirmed its activity against tumour $(9,10)$. In order to explore whether it can treat live cancer and its potential mechanism, some experiments were designed to investigate the effect of ethanol extract of $A$. senticosus (ASE) on proliferation and apoptosis of human hepatocarcinoma cells (HepG2 cells). We found that ASE can induce apoptosis in HepG2 cells, and functional proteomic analysis indicated that ASE can reduce the protein expression levels of Matrix metalloproteinase-2 (MMP-2), MMP-9, protein kinase $\mathrm{B}(\mathrm{Akt})$, and increased the protein expression level of E-cadherin. In addition, inhibitory activity of ASE against nuclear factor kappa B (NF-kB) was also evaluated.

Nuclear factor kappa beta $(\mathrm{NF}-\kappa \mathrm{B})$, a complex transcription of factor, is responsible to mediate the connection between cell cycle, inflammation and cell survival linked with carcinogenesis (11). This transcription factor maintains an inactive state and it exists in the cytoplasm of all cells bound to the members of the inhibitor

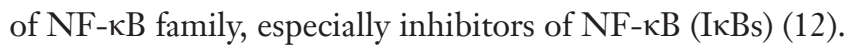
When stimulation occurs, I $\kappa$ Bs are phosphorylated and then the activated $\mathrm{NF}-\mathrm{\kappa B}$ dimer enters the nucleus and combines with deoxyribonucleic acid (DNA) to regulate gene transcription. Target genes expressed by NF$\kappa \mathrm{B}$ are frequently involved in many diseases, such as atherosclerosis, diabetes mellitus and cancer (13). Thus, exploring the inhibition of ASE on $\mathrm{NF}-\mathrm{KB}$ is essential to investigate the mechanism of ASE-induced apoptosis in liver cancer cells.

In order to develop new drug, just like artemisinin isolated from herb, we try to explore the active compound in ASE which was against NF- $\mathrm{KB}$ using high performance liquid chromatography (HPLC) and fourteen compounds were isolated including seven active compounds.

\section{Methods}

\section{Reagents}

The kits and reagents were purchased from Beyotime Biotechnology Research Institute (Shanghai, China). All monoclonal antibodies, including anti-Akt, anti-p-Akt, antiE-cadherin, anti-MMP-2, anti-MMP-9 and anti- $\beta$-actin were got from Jianglai Biotechnology (Beijing, China). Fetal bovine serum (FBS) was purchased from Tianhang Biological Polytron Technology (Zhejiang, China). Roswell
Park Memorial Institute- 1640 (RPMI-1640) medium was purchased from Thermo Fisher Scientific biochemistry (Beijing, China). WelFect M Gold was purchased from WelGENE Inc (Gyeongsangbuk-do, Korea).

\section{Preparation of plant extract}

The stems of ASE were obtained from Jilin city, Jilin province, China. The stems were dried followed by placing it in a dry and well-ventilated room. After being crushed into powder, $70 \%$ ethanol was used to isolate the stems of ASE and this step was repeated three times. Furthermore, the solution was concentrated to obtain a crude extract with rotary evaporators. In addition, dimethyl sulfoxide (DMSO) was used to dissolve powders and the solution was stored at room temperature until use.

\section{Cell culture}

HepG2 cells were cultured in RPMI-1640 medium containing $10 \% \mathrm{FBS}, 1 \%$ L-glutamine, $0.1 \mathrm{mg} / \mathrm{mL}$ streptomycin and 100 units $/ \mathrm{mL}$ penicillin. Cells were incubated in a humidified incubator with $5 \% \mathrm{CO}_{2}$ at $37{ }^{\circ} \mathrm{C}$ and cells were used for all experimental treatments at approximately $70 \%$ confluence.

\section{Cell viability and apoptosis assays}

Cell viability was determined by MTT (3-(4,5-dimethyl2-thiazolyl)-2,5-diphenyl-2 -H-tetrazolium bromide) method (14). The concentration of HepG2 cells was diluted to $2 \times 10^{5} / \mathrm{mL}$ in RPMI-1640 medium, which contained $10 \%$ FBS. Cells were seeded in a 96 -well plate and there were $100 \mu \mathrm{L}$ cell suspension in every well. Then cells were cultured for $24 \mathrm{~h}$, and treated with low$(40 \mu \mathrm{g} / \mathrm{mL})$, medium- $(80 \mu \mathrm{g} / \mathrm{mL})$ and high-concentration $(120 \mu \mathrm{g} / \mathrm{mL})$ ethanol extract for another $24 \mathrm{~h}$. Before the end of cultivation, supernatant was abandoned and the sterile phosphate buffer saline (PBS) buffer was used to wash cells. Each well was filled with MTT reagent $(5 \mathrm{mg} / \mathrm{mL}$, $20 \mu \mathrm{L}$ ), then cells were incubated for $4 \mathrm{~h}$. Finally, $150 \mu \mathrm{L}$ dimethyl sulfoxide (DMSO) was added into each well, which was gently shaked for $15 \mathrm{~min}$ in order to make cells blending. Optical density (OD) value of each well was measured by Tecan infinite M200 microplate reader at $570 \mathrm{~nm}$. Cell growth inhibitory rate was calculated according to the following formula: Cell growth inhibitory rate $=(1-$ OD value in treating group/OD value in control group) 
$\times 100 \%$. Apoptosis was quantified using Annexin V and propidium iodide (PI) staining for DNA fragmentation by flow cytometry analysis according to established method (9). HepG2 cells were treated with $120 \mu \mathrm{g} / \mathrm{mL}$ of extract for $72 \mathrm{~h}$, washed with PBS, and harvested. Cell pellets were washed and resuspended in $1 \mathrm{~mL}$ of binding buffer. The cell suspension was stained with annexin V-FITC and PI followed by incubating for $10 \mathrm{~min}$ at room temperature in the dark. Cell cycle distribution and the percentage of apoptotic cells were analyzed by using a Becton Dickinson FACS Calibur flow cytometer and CellFit software (CA, USA). In addition, TdT-mediated dUTP Nick-End Labeling (TUNEL) assay was further used to confirm treatment-induced apoptosis. Briefly, HepG2 cells were grown on Nunc ${ }^{\mathrm{TM}} \mathrm{Lab}^{\mathrm{Te}} \mathrm{K}^{\mathrm{TM}}$ II chamber slide (Thermo Fisher Scientific, Shanghai, China), washed once with PBS, and fixed in $100 \%$ methanol at $-20{ }^{\circ} \mathrm{C}$ for $10 \mathrm{~min}$. The fixed cells were blocked in blocking buffer $[0.05 \%$ Tween-20 and $1 \%$ bovine serum albumin (BSA) in $1 \times \mathrm{PBS}$ ] for $1 \mathrm{~h}$, and washed three time with $1 \times$ PBS (15). Then cells were mounted with UltraCruz Mounting Medium (Santa Cruz, CA, USA), and incubated with the TUNEL staining solution overnight at $4{ }^{\circ} \mathrm{C}$ and washed three times with 1 $\times$ PBS. Finally, fluorescent microscopy (MicroTEQ-A1, Shanghai, China) was used to examine the cells.

\section{Clonogenicity assay}

The clonogenicity test was performed as described (16). HepG2 cells were seeded at a density of $3 \times 10^{5}$ cells/well in 6-well plates. After $24 \mathrm{~h}$ of incubation, low-, medium- and high-concentration ethanol extract were added to cells and the control samples received DMSO alone. In addition, 5 -fluororacil was also added to cells to be a positive control. Cells were cultured for three weeks in a humidified incubator with $5 \% \mathrm{CO}_{2}$ at $37{ }^{\circ} \mathrm{C}$. After washing with $1 \times \mathrm{PBS}$, the cells were fixed with $1 \mathrm{~mL}$ methanol and stained with Giemsa solution to visualize colonies. The colony of more than 50 cells was counted using an inverted microscope and the inhibitory rate was calculated according to the following formula: Clonogenicity inhibitory rate $=(1-$ the number of colony in treating group/that in control group) $\times 100 \%$.

\section{The effect of ethanol extract on invasion of liver cancer cells}

This experiment included covering Transwell chamber with basement membrane, hydrating basement membrane, preparing cell suspension, cell inoculation, fixation and dye. Firstly, the Matrigel gel was diluted to $200 \mathrm{~g} / \mathrm{mL}$ with the cold serum free-RPMI 1640 medium. One hundred $\mu \mathrm{L}$ mixed solution was added into the upper chamber of Transwell chamber and cells were cultured for $4 \mathrm{~h}$ in a humidified incubator at $37^{\circ} \mathrm{C}$. When solution coagulated, the excess liquid was discarded. Secondly, $600 \mu \mathrm{L}$ cold serum free-RPMI 1640 medium were added to chambers of Transwell. The basement membrane was hydrated for 30 min at $37^{\circ} \mathrm{C}$. Next, HepG2 cells in logarithmic growth phase were digested with $0.25 \%$ trypsin, washed three times with fresh culture medium, diluted to $5 \times 10^{5} / \mathrm{mL}$ with RPMI- 1640 medium containing $10 \mathrm{mg} / \mathrm{mL}$ BSA and treated with three different concentration ethanol extract, respectively. Finally, 200 $\mathrm{L}$ cell suspensions in different groups were seeded in the upper Transwell chambers and $500 \mu \mathrm{L}$ RPM 1640 medium were added to lower Transwell chambers followed by culturing for $48 \mathrm{~h}$. Transwell chambers were fixed with cold methanol, stained with crystal violet solution, and observed and took picture using an inverted microscope.

\section{RNA extraction and Reverse Transcription-Polymerase Chain Reaction (RT-PCR) assay}

HepG2 cells were seeded at a density of $1 \times 10^{6}$ cells in $100 \mathrm{~mm}$ plate, treated with three concentration extract and cultured for $72 \mathrm{~h}$ in a humidified incubator with $5 \%$ $\mathrm{CO}_{2}$ at $37{ }^{\circ} \mathrm{C}$. Total ribonucleic acid (RNA) was isolated according to a series of established methods using the TRIzol reagent. Spectrophotometry method was used to determine the concentration of total RNA in the final eluates. Each sample was reverse-transcribed to cDNA using established methods. Briefly, $1 \mu \mathrm{g}$ templet RNA and $1 \mu \mathrm{L}$ Random primer $(250 \mu \mathrm{mol} / \mathrm{L})$ were added to cold RNase free tube and then DEPC $\mathrm{H}_{2} \mathrm{O}$ was added to $13 \mu \mathrm{L}$. After keeping $65{ }^{\circ} \mathrm{C}$ temperature for $10 \mathrm{~min}$, they were chilled on ice for $2 \mathrm{~min}$. Next, $5 \mu \mathrm{L} 5 \times$ RT Reaction Buffer, $1 \mu \mathrm{L} 25 \mathrm{mmol} / \mathrm{L}$ dNTP, $1 \mu \mathrm{L} 200 \mathrm{U} / \mu \mathrm{L}$ M-MLV RTase, $1 \mu \mathrm{L} 25 \mathrm{U} / \mu \mathrm{L}$ RNase inhibitor and $4 \mu \mathrm{L}$ DEPC $\mathrm{H}_{2} \mathrm{O}$ were added to RNase free tube. The mix solution was cultured for $1 \mathrm{~h}$ at $37^{\circ} \mathrm{C}$, and chilled on ice water after keeping $70{ }^{\circ} \mathrm{C}$ for $15 \mathrm{~min}$. Then cDNA was produced followed by storing at $-20^{\circ} \mathrm{C}$. PCR was performed with specific primers for the following genes; MMP-2 (628 bp): sense 5' -GGCTGCCCTCCCCTTGTTTCCG-3'; antisense 5' -TTGGCCACATCTGGGTTGCCG-3'; MMP-9 (569 bp): sense 5' -GCCACGCGCTGGGCTTAGAT-3'; 
antisense 5' - CGCGCCTGTGTACACCCACA-3'. PCR products were electrophoresed on $2 \%$ agarose gels and visualized by staining with ethidium bromide. Then the amount of PCR products in the four groups were compared.

\section{Western blot analysis}

According to established methods, the Western blot analysis was performed (15). Cell lysates were subjected to $10 \%$ SDS-polyacrylamide gel electrophoresis (SDSPAGE) and transferred to polyvinylidene fluoride (PVDF) membranes (15). After blocking PVDF membranes with 5\% nonfat powdered milk, membranes were washed three times with TBST (50 m MTris/ $\mathrm{HCl} \mathrm{pH}$ 7.4, $150 \mathrm{mM} \mathrm{NaCl}$, $0.1 \%$ Tween 20) and each time was $5 \mathrm{~min}$. Membranes were incubated with specific primary antibodies (dilution 1:200) for $12 \mathrm{~h}$ at $4{ }^{\circ} \mathrm{C}$, washed with TBST three times, and exposed to secondary antibody (dilution 1:10,000) at room temperature for $1 \mathrm{~h}$. After washing three times again with TBST with $10 \mathrm{~min}$, membranes were stained using the Enhanced chemiluminescence (ECL) Western Blotting Kit according to the manufacturer's specifications. Eventually, films were took and the light density of target bar was analyzed by ImageJ software.

\section{The effect of extract on the cytoskeleton}

HepG2 cells were seeded in a 6-well plate, and treated with three different concentration extract, cultured for $24 \mathrm{~h}$. Then cells were washed with $2 \times$ phosphate buffer saline (PBS) and fixed with $2 \%$ paraformaldehyde and $2.5 \%$ glutaraldehyde for $15 \mathrm{~min}$. Moreover, $0.5 \%$ TritonX-100 and TRITC phalloidin were added to cells in order to stain F-actin in fixed cells. In the same way, the fine filaments of cells were stained using $5 \mathrm{mg} / \mathrm{L}$ myosin IIB which was labeled by fluorescein isothiocyanate (FITC). The changes of cell morphology and the arrangement and distribution of F-actin and myosin IIB were observed using confocal microscopy.

\section{$N F-\kappa B$-Luciferase assay}

HepG2 cells were first transfected with the luciferase vector. Then cells were lysed after a limited amount of time. Next, the luciferin, the substrate of luciferase, $\mathrm{Mg}^{2+}$ and an excess of adenosine triphosphate (ATP) were introduced into the cellular extract. Under these conditions, luciferase enzymes expressed by the reporter vector could catalyzed the oxidative carboxylation of luciferin. Then cells were seeded at a density of $1.5 \times 10^{5}$ cells per well in 6 -well plates and grown for $24 \mathrm{~h}$ until the density was $50-70 \%$. All cells were transfected with WelFect M Gold according to the manufacturer's instructions. The transfected cells were pretreated with three different concentration extract for $1 \mathrm{~h}$, followed by treating $10 \mathrm{ng} / \mathrm{mL}$ TNF $\alpha$ for $1 \mathrm{~h}$. The unstimulated HepG2 cells were used as a negative control. Finally, cells were harvested and the luciferase activity was assayed. The luciferase activity was measured using an LB 953 Autolumat (EG\&G Berthold, Nashua, NH, USA).

\section{Extraction and isolation of compounds using HPLC}

ASE extract was chromatographed over a silica gel column using a gradient of $\mathrm{CH}_{2} \mathrm{Cl}_{2} / \mathrm{MeOH}$ (from 50:1, 30:1 to 1:1), then it was separated into nine fractions (Fr.1-Fr.9). Furthermore, Fr.6 (2.9 g) was investigated and part of Fr.6 (120.0 mg) was applied to $\mathrm{C}_{18}$ reversed-phase HPLC column $(10 \times 250 \mathrm{~mm}, 10 \mathrm{~m})$ and eluted with a gradient of $\mathrm{MeOH}-\mathrm{H}_{2} \mathrm{O}(50: 50-75: 25)$ at a flow rate of $3.0 \mathrm{~mL} / \mathrm{min}$. This resulted in the isolation of four compounds, compound $1(15 \mathrm{mg})$, compound $2(9 \mathrm{mg})$, compound 3 (20 mg), compound $4(27 \mathrm{mg})$, compound $5(5 \mathrm{mg})$, compound 6 (16 mg), compound $7(21 \mathrm{mg})$. The inhibitory activities of the seven active compounds on $\mathrm{NF}-\kappa \mathrm{B}$ were evaluated by step of 2.9 and sulfasalazine was used to be a positive control.

\section{Statistical analysis}

Data were expressed as means \pm Standard Deviation (SD). Statistical comparisons of the results were made by one way Analysis of Variance (ANOVA) analysis using the statistical software package Statistical Product and Service Solutions (SPSS) 22.0 (International Business Machines, corp., Armonk, NY, USA). A $\mathrm{P}<0.05$ was considered to be statistically significant.

\section{Results}

\section{Ethanol extract of ASE inbibited the viability of liver cancer HepG2 cells}

The effect of the ASE on cell viability was first examined by MTT assay. The data of assay clearly showed that the viability of the HepG2 cells was inhibited in a 


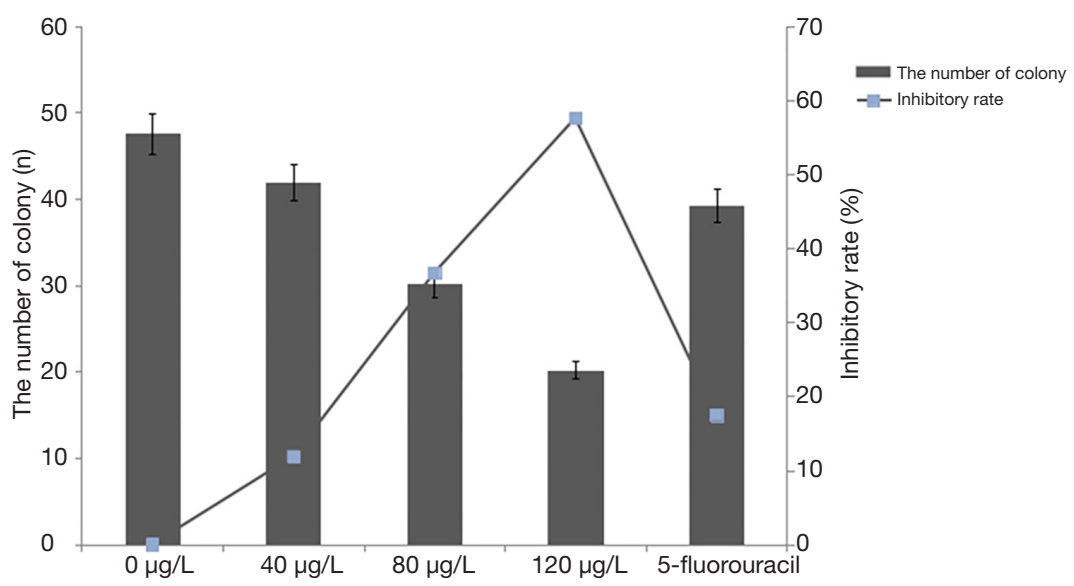

Figure 1 MTT and clonogenicity assays showed the extract of Acanthopanax senticosus inhibited the viability and clonogenicity of HepG2 cells

dose- and time-dependent manner after treatment with different concentration ethanol extract. In comparison with control group, the high concentration group significantly inhibited the viability of HepG2 cells after treating for 24 and $48 \mathrm{~h}(\mathrm{P}<0.05)$ (Figure 1). The results of clonogenicity assay showed that the clonogenicity of HepG2 cells was significantly inhibited after treating with three concentration ethanol extract in comparison with the control group $(\mathrm{P}<0.05)$. Among the three groups, the inhibitory rate of high concentration group on HepG2 cells was as high as $57.55 \%$.

\section{Ethanol extract of ASE induced the apoptosis of HepG cells}

The change of apoptosis rate of HepG2 Cells in the control group and treated group were analyzed using Annexin V and PI (15). Our results showed that ethanol extract of ASE could induce apoptosis of HepG cells (Figure 2A). Apoptosis rate of HepG2 Cells was $20.7 \% \pm 0.5 \%$ and $36.4 \% \pm 0.2 \%$ in medium and high concentration groups, respectively (Figure $2 A$ ). In addition, flow cytometry showed that the ethanol extract increased the amount of subG1 cells in a dose-dependent manner. It produced approximately $33 \%$ of sub-G1 cells at the concentration of $120 \mu \mathrm{g} / \mathrm{mL}$ (Figure 2B). Furthermore, TUNEL assay further confirmed that the ethanol extract significantly increased the number of positive cells (Figure 2C).

\section{Ethanol extract of ASE inbibited invasion of HepG2 cells}

To investigate the effect of ethanol extract on invasion of
HepG2 cells, we performed Transwell assay. Our results showed that the number of cells passing through the basement membrane was decreased after treating with three concentration extract when compared to the control group $(\mathrm{P}<0.05)$ (Figure 3A). The number of cells in medium and high concentration groups were decreased by $24.4 \%$ and

$42.7 \%$, respectively (Figure $3 A, B$ ).

\section{Genomic and proteomic analysis identified 2 proteins associated with the extract-induced apoptosis}

RT-PCR assay showed that the mRNA expression levels of MMP-2 and MMP-9 in the treat groups were decreased in comparison with those in the control group. The mRNA expression levels of MMP-2 in the three treated groups were decreased by $19.1 \%, 23.3 \%$ and $60.1 \%$, respectively $(\mathrm{P}<0.05)$ (Figure $4 A)$. In addition, the mRNA expression levels of MMP-9 in the three treat groups were decreased by $40.5 \%, 49.2 \%$ and $77.6 \%$, respectively $(\mathrm{P}<0.05)$ (Figure $4 B)$. Furthermore, the Western blot showed that the protein expression levels of MMP-2 and MMP-9 in treat groups were obviously decreased in comparison with those in the control group (Figure 5A). The expression levels of MMP2 and MMP-9 in treat groups were decreased by $26.5 \%$, $36.6 \%$ and $57.3 \% ; 36.6 \%, 48.8 \%$ and $68.7 \%$, respectively $(\mathrm{P}<0.05)$ (Figure 5).

\section{Ethanol extract of ASE inbibited the expression of Akt and E-cadherin protein}

The Western blot assay showed there was significant 


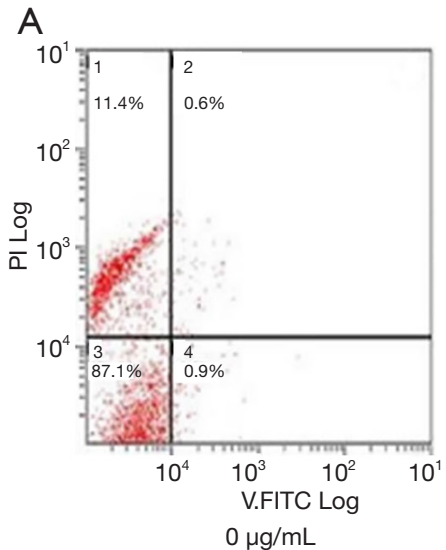

B

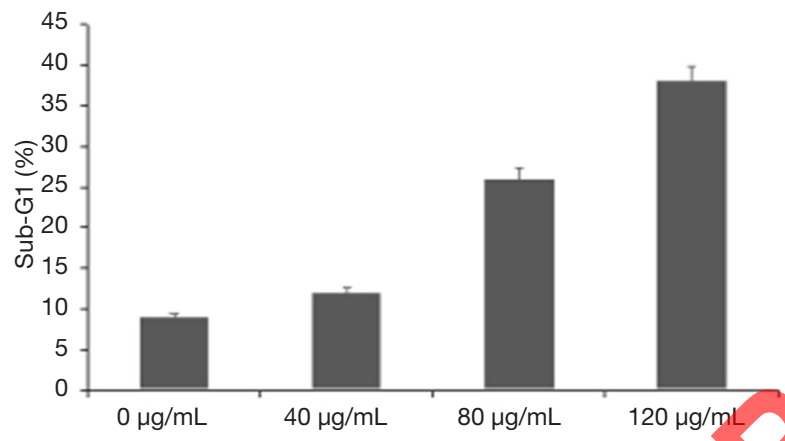

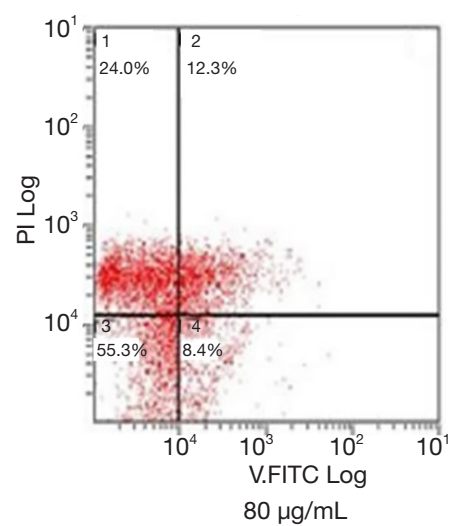

C

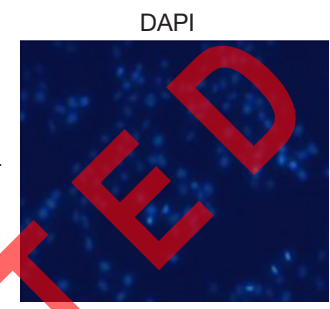

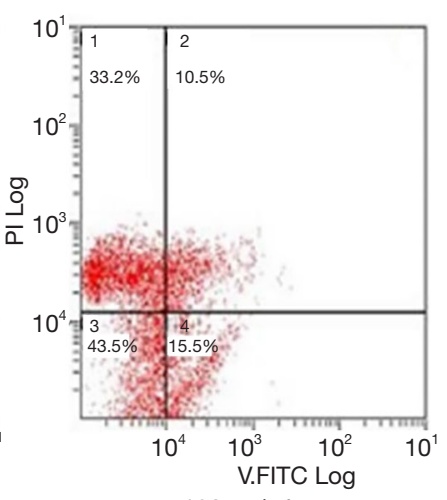

$120 \mu \mathrm{g} / \mathrm{mL}$
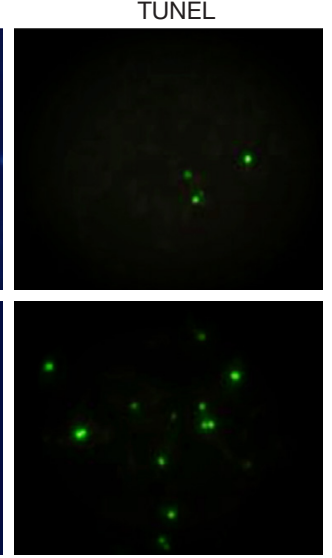

Figure 2 Flow cytometric analysis exhibited that extract induced apoptosis of HepG2 cells (A) The elevated G1 arrest in cell cycle by extract was assessed by flow cytometry; data represent the mean \pm SD of three independent experiments (B); TUNEL assay outcome (C).
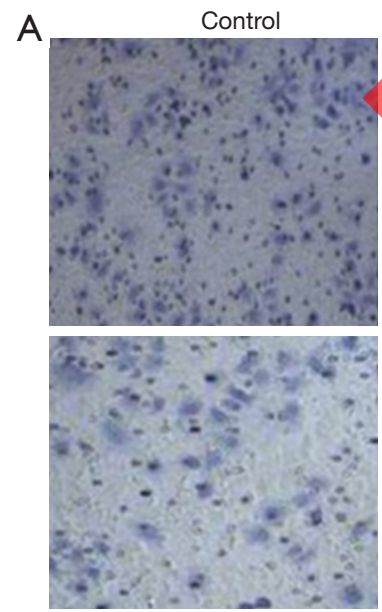

$80 \mu \mathrm{g} / \mathrm{mL}$
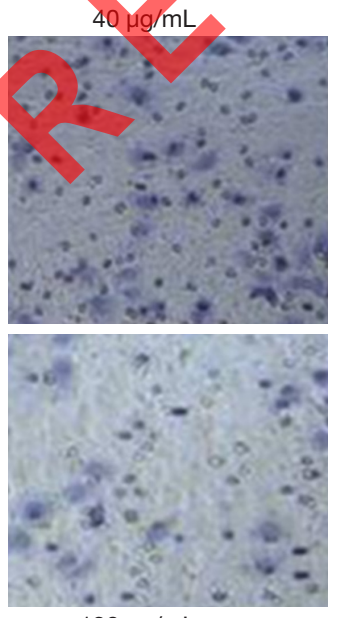

$120 \mu \mathrm{g} / \mathrm{mL}$
B

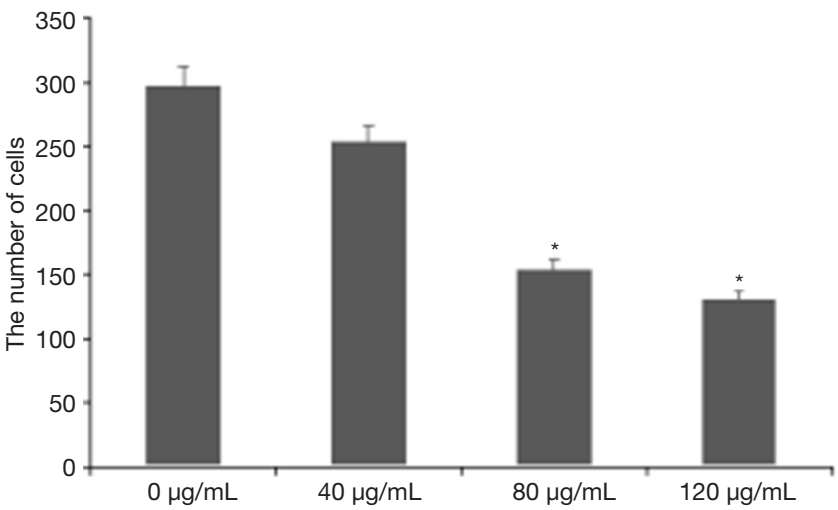

Figure 3 Transwell chamber showed the inhibitory activity of extract on invasion of cancer cells. (A) The number of cells passing through the basement membrane (stained with crystal violet solution; 100x); (B) the comparison of the number of cells in four groups. *, $\mathrm{P}<0.05$ compared with the normal group. 

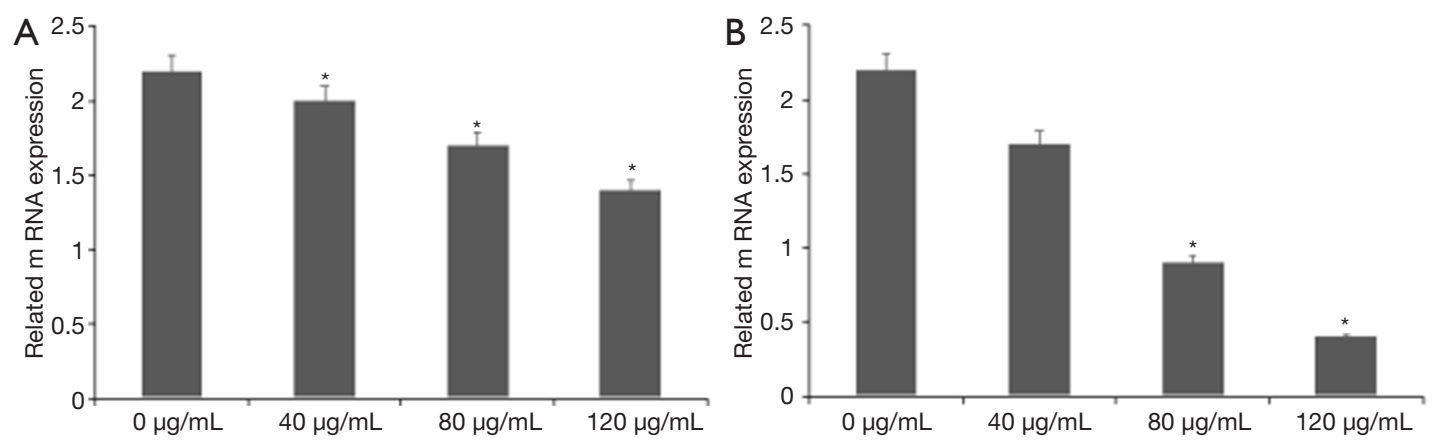

Figure 4 Rt-PCR assay showed the effect of extract on the expression of MMP-2 mRNA (A) and MMP-9 mRNA (B) in HepG2 cells. *, $\mathrm{P}<0.05$ compared with the normal group.

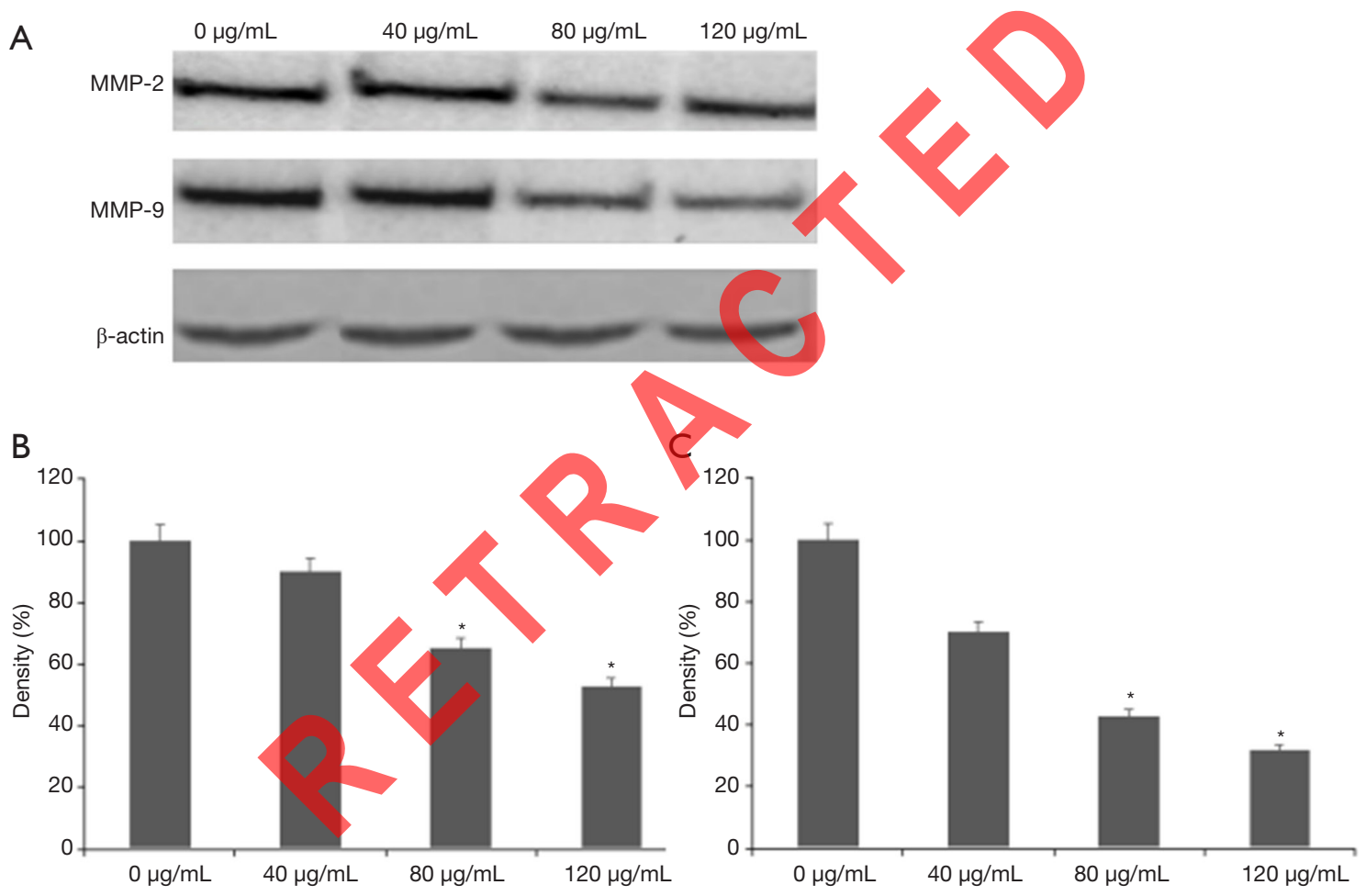

Figure 5 The Western blot assay showed the effect of extract on the expression of MMP-2 (B) and MMP-9 (C) proteins in HepG2 cells. The protein levels of MMP-2 and MMP-9 were decreased after treatment with extract. (A) *, $\mathrm{P}<0.05$ compared with the normal group.

difference between treat groups and control group and the protein expression levels of t-Akt were decreased by $65.26 \%$ after treating with high concentration extract $(\mathrm{P}<0.05)$ (Figure 6A,B). However, the protein expression levels of $\mathrm{t}$-Akt had no obvious change after treating with low concentration ethanol extract (Figure 6A,B). In addition, the expression levels of p-Akt were decreased by $30.51 \%$ after treating with high concentration ethanol extract
$(\mathrm{P}<0.05)$ (Figure 6A,C). The protein expression levels of p-Akt had no change after treating with low concentration extract. Furthermore, the results displayed that ethanol extract can promote the expression levels of E-cadherin in HepG2 cells (Figure 7A). The protein expression levels of E-cadherin were obviously increased by $47.8 \%$ and $156.4 \%$ after treating with medium and high concentration ethanol extract $(\mathrm{P}<0.05)$ (Figure 7). 

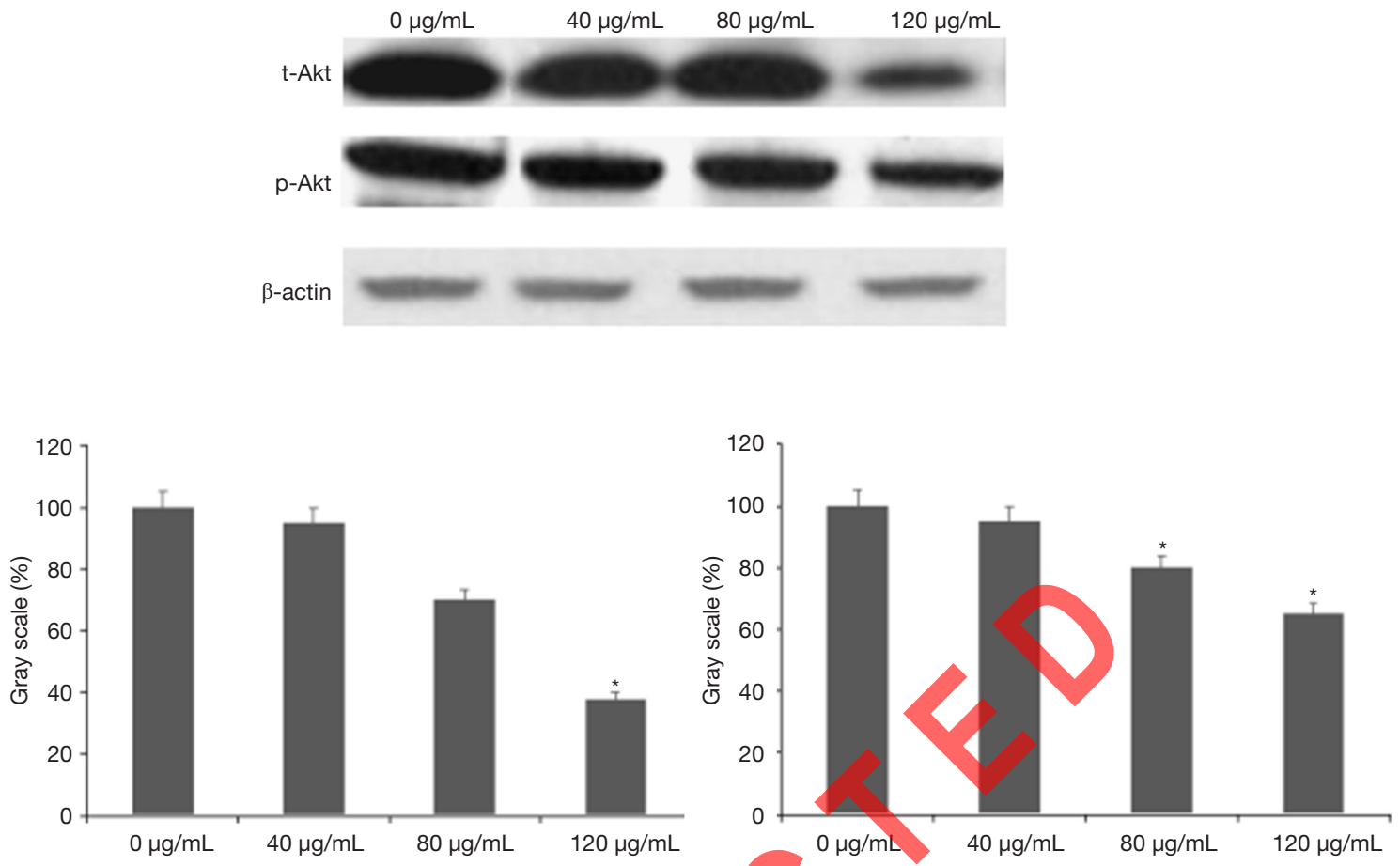

Figure 6 The Western blot assay showed the effect of extract on the expression of Akt protein in HepG2 cells. The protein levels of t-Akt and p-Akt. (A) The expression level of t-Apt in four groups; (B) the expression level of P-Akt in four groups $(\mathrm{C}) .{ }^{*}, \mathrm{P}<0.05$ compared with the normal group.
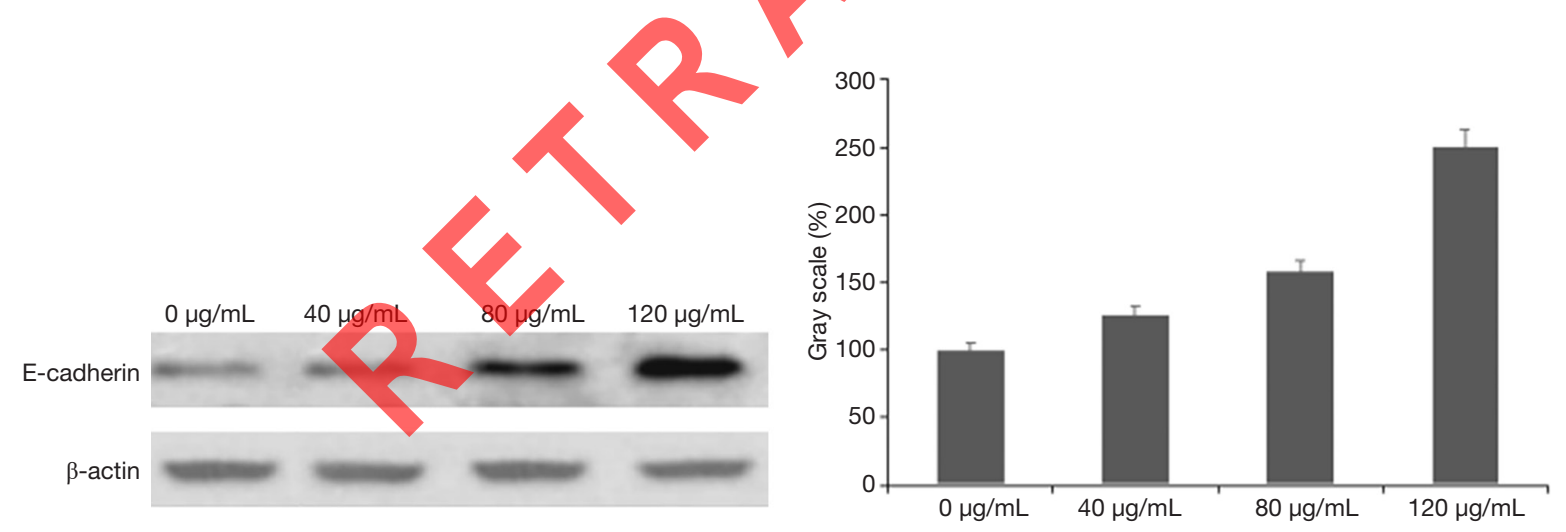

Figure 7 The Western blot assay showed the effect of extract on the expression of E-cadherin protein in HepG2 cells. Western blot analysis showed the extract can up-regulated the level of E-cadherin. (A) The expression level of E-cadherin in four groups was compared (B).

\section{Ethanol extract of ASE supported the cytoskeleton of HepG2 cells}

In order to explore the effects of ethanol extract on the distribution and morphology of cytoskeletal proteins, we stained F-actin of HepG2 cells using TRITC phalloidin and stained fine filaments with myosin IIB which was labeled by FITC. Our results showed that the fluorescence intensity of F-actin in treated groups was significantly increased. Furthermore, fluorescence intensity of myosin IIB was also increased and stress fiber became thick to support cytoskeleton (Figure 8).

\section{ASE inbibited NF-кB in HepG2 cells}

MTT assay and flow cytometry have showed that ASE 


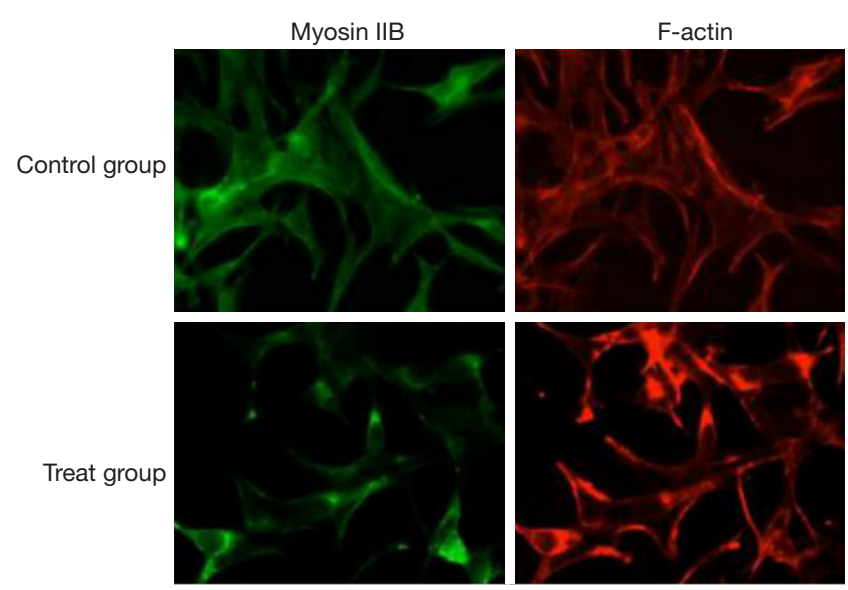

Figure 8 Laser scanning confocal microscope showed the effect of extract on the cytoskeleton of HepG2 cells, 200x.

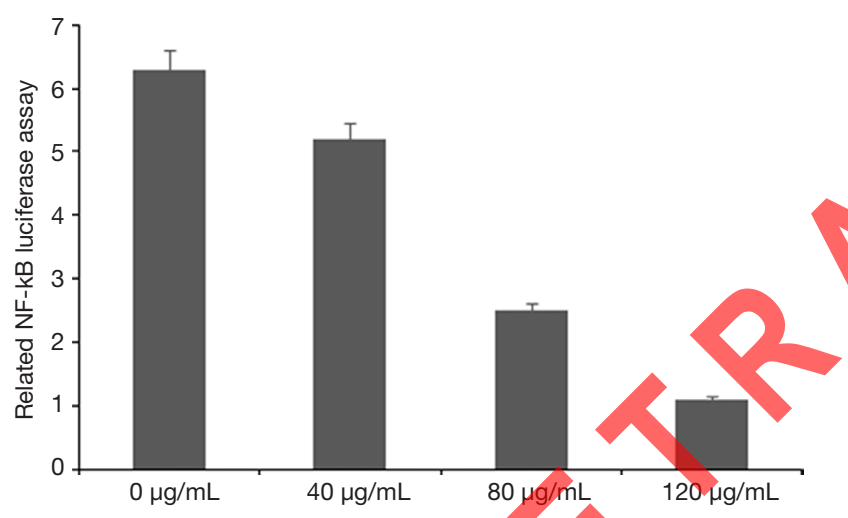

Figure $9 \mathrm{NF}-\kappa \mathrm{B}$-Luciferase assay showed extract inhibited the activity of $\mathrm{NF}-\kappa \mathrm{B}$.
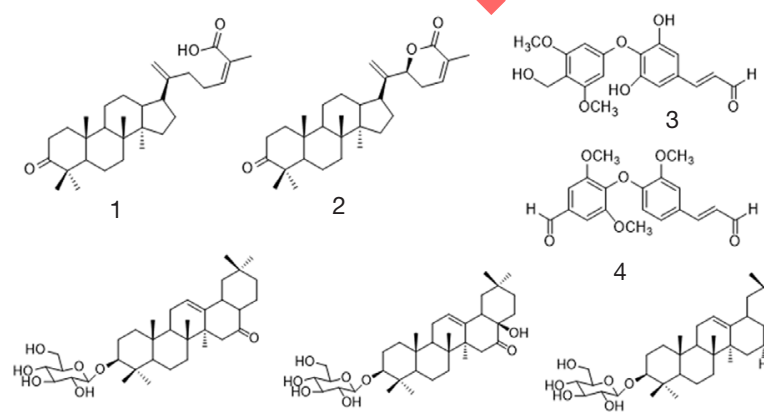

5
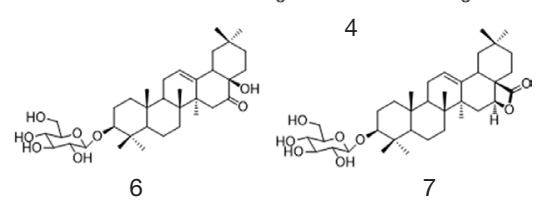

Figure 10 Seven active compounds isolated from $A$. senticosus. inhibited proliferation and clonogenicity and decreased the amount of HepG2 cells. NF-кB was closely related to clonogenicity, cell survival, and proliferation, so we investigated the effect of ASE on NF-кB. To understand whether ASE regulated NF- $\mathrm{BB}$-dependent gene transcription, we first transfected HepG2 cells with luciferase vector. Next, all cells were transfected with WelFect M Gold, then treated with three different concentration ethanol extract for $1 \mathrm{~h}$. The results showed that ASE inhibited NF-kB-responsive luciferase expression and the high concentration group has the higher inhibitory activity on $\mathrm{NF}-\kappa \mathrm{B}$ in comparison with other groups (Figure 9).

Seven known compounds with inhibitory active on $\mathrm{NF}-\kappa \mathrm{B}$ were identified by the spectroscopic and physicochemical analyses and comparison with literature values including 24-(Z)-3-oxo-dammar-20(21), 24-dien-27oic acid [1] (17),22(S)-3-oxodammar-20, 24-dien26, 22-lactone [2] (17), 3-[3',5'-dihydroxy-4'-(4'"hydroxymethyl-3", 5"'-dimethoxy-phenoxy)-phenyl)propenal [3] (6), 3-[3'-methoxy-4'-(4"'-formyl-2" ,6"'dimethoxy-phenoxy)-phenyl)-propenal [4] (6), 3ß-hydroxy28-norolean-12-ene-16-one 3-O- $\beta$-D-glucopyranoside [5] (18), 3 $\beta, 17 \beta$-dihydroxy-28-norolean-12-ene-16-one 3-O- $\beta$-D-glucopyranoside [6] (18), 3 $\beta$-hydroxy-olean12 -ene-16,28-lactone 3-O- $\beta$-D-glucopyranoside [7] (18) (Figure 10). The inhibitory activity of those seven active compounds on NF- $\kappa \mathrm{B}$ was showed in Table 1. Among them, compound 6 showed high inhibitory activity with $\mathrm{IC}_{50}$ values of $7.2 \pm 1.3 \mu \mathrm{M}$, compound 1,2 and 5 exhibited moderate inhibitory activity with $\mathrm{IC}_{50}$ values ranging from $11.4 \pm 1.2$ to $22.1 \pm 1.2 \mu \mathrm{M}$ (Table 1 ).

\section{Discussion}

Natural products are getting more and more attention as a useful resource and potential therapy for treating a variety of diseases (19). It is worth mentioning that the use of natural products to treat diseases is not a new research topic. In the area of cancer, natural products or their derivatives were developed as anti-cancer small molecule drugs from 1940 to 2010 (20). This study showed that ASE extract had strong inhibitory activity against HepG2 cells in a timeand dose-dependent manner and it was evidenced by data 
Table 1 Inhibitory effects of compounds 1-7 on NF- $\mathrm{BB}$ activity (expressed as $\mathrm{IC}_{50}$ values)

\begin{tabular}{lc}
\hline Compounds & $\mathrm{IC}_{50}\left(\mu \mathrm{mol} \cdot \mathrm{L}^{-1}\right)$ \\
\hline 1 (Figures S1,S2) & $22.1 \pm 1.2$ \\
2 (Figures S3,S4) & $14.4 \pm 1.5$ \\
3 (Figures S5,S6) & $89.3 \pm 2.3$ \\
4 (Figures S7,S8) & $85.2 \pm 0.7$ \\
5 (Figures S9,S10) & $11.4 \pm 1.2$ \\
6 (Figures S11,S12) & $7.2 \pm 1.3$ \\
7 (Figures S13,S14) & $>100$ \\
Sulfasalazine (positive control) & $1.1 \pm 0.3$ \\
\hline
\end{tabular}

The samples were tested for $\mathrm{NF}-\kappa \mathrm{B}$ inhibitory activity in three independent experiments.

from MTT and clonogenicity assay. The results of flow cytometry and TUNEL assays confirmed that extract can cause apoptosis of HepG2 cells. In addition, the invasion of HepG2 cells is one of the important cause of recurrence and death. Transwell assay was used to evaluate the effect of invasion in HepG2 cells. Results showed that the number of cells passing through the basement membrane was decreased after treating with three concentration extract, which indicated extract can inhibited the invasion of HepG2 cells.

Proteomic analysis revealed 5 proteins which were responsive to the treatment by extract. The tumour cells degraded the extracellular matrix mainly by secreting MMPs. Among MMPs family, MMP-2 and MMP-9 are key enzymes in degradation of type IV collagen (21), which cause the metastasis of cancer cells. The results of Western blot showed that extract could effectively inhibited the protein expression of MMP-2 and MMP-9. And RT-PCR assay could also confirm it. Akt is the major molecule in the phosphatidylinositol 3-kinase (PI3K)/Akt signaling pathway which involve regulating cell cycle, angiogenesis, protein synthesis, cell invasion and metastasis (22). When cancer occurs, the PI3K/Akt signaling pathway is activated and the expression level of Akt is increased. We found that extract inhibited the expression of Akt. The results showed that high concentration extract decreased the expression level of Akt by $65.26 \%$, which indicated the effect of extract on Akt was significant. In addition, the effect of extract on E-cadherin also be studied. Abnormal expression of E-cadherin can also lead to metastasis of cancer cells through reducing adhesion between tumor cells (23). Our results showed that extract can promote the expression of E-cadherin to increase the adhesion of cancer cells.

The cytoskeleton is composed of intracellular proteins, which mainly including microtubules, microfilaments and medium fiber. Actin is the major component of Microfilament. Some studies have confirmed that F-actin and myosin are involved in cell movement (24). The distribution and changes of $\mathrm{F}$-actin and myosin IIB in HepG2 cells were observed by laser scanning confocal microscopy. Results showed the fluorescence intensity of $\mathrm{F}$-actin and myosin IIB proteins in cells was significantly enhanced after treating with extract. It indicated that the amount of F-actin and myosin IIB were increased and cytoskeleton was supported by increased stress fiber. However, whether extract can inhibit the metastasis of cancer cells by altering the composition of $\mathrm{F}$-actin and myosin IIB should be further studied.

To investigate the mechanism of ASE-induced apoptosis in HepG2 cells, we evaluated the inhibitory activity of extract against $\mathrm{NF}-\kappa \mathrm{B}$ using luciferase assay. Results demonstrated that ASE effectively inhibited NF$\kappa \mathrm{B}$ aetivity in HepG2 cells in a dose-dependent manner. However, detailed mechanism of inhibiting activity of $\mathrm{NF}-\kappa \mathrm{B}$ need to be further investigated. In addition, we also isolated fourteen compounds including seven active compounds using HPLC in order to transform herb into chemical drug just like artemisinin. Results showed that compound 6 had high inhibitory activity and compound 1,2 and 5 exhibited moderate inhibitory activity. These results provided an important implication that ASE did has several compounds which inhibited the activity of NF- $\mathrm{\kappa B}$ to treat liver cancer. Other possible mechanisms of ASE extract or compounds on liver cancer cell death also need to be studied.

\section{Conclusions}

Our study showed that ASE stems could decrease the amount of HepG2 cells, support the cytoskeleton, inhibit the metastasis of cancer cells by decreasing the expression of MMP-2, MMP-9, Akt, p-Akt and promoting the expression of E-cadherin. In addition, this experiment indicated that ASE most likely induced apoptosis of HepG2 cells by inhibiting NF- $\mathrm{KB}$ activity and further investigation including the effect of ASE on NF- $\kappa \mathrm{B}$-regulated transcription of genes still need to be done. 


\section{Acknowledgments}

Funding: This project was finally supported by a grant of the Natural Science Foundation of China (No. 81502069); Natural Science Fund Project of Shandong Province (No. BS2015YY025 and ZR2015HL084); Scientific Research Foundation of Binzhou Medical University (BY2014KYQD35).

\section{Footnote}

Conflicts of Interest: The authors have completed the ICMJE uniform disclosure form (available at http://dx.doi. org/10.21037/tcr.2020.01.02). The authors have no conflicts of interest to declare.

Ethical Statement: The authors are accountable for all aspects of the work in ensuring that questions related to the accuracy or integrity of any part of the work are appropriately investigated and resolved.

Open Access Statement: This is an Open Access article distributed in accordance with the Creative Commons Attribution-NonCommercial-NoDerivs 4.0 International License (CC BY-NC-ND 4.0), which permits the noncommercial replication and distribution of the article with the strict proviso that no changes or edits are made and the original work is properly cited (including links to both the formal publication through the relevant DOI and the license). See: https://creativecommons org/licenses/by-ncnd/4.0/.

\section{References}

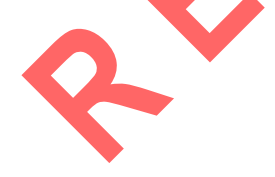

1. Ferlay J, Soerjomataram I, Dikshit R, et al. Cancer incidence and mortality worldwide: sources, methods and major patterns in GLOBOCAN 2012. Int J Cancer 2015;136:E359-86.

2. Henry SH, Bosch FX, Bowers JC. Aflatoxin, Hepatitis and Worldwide Liver Cancer Risks. Adv Exp Med Biol 2002;504:229-33.

3. Kim HJ, Kim JC, Min JS, et al. Aqueous extract of Tribulus terrestris Linn induces cell growth arrest and apoptosis by down-regulating NF- $\mathrm{KB}$ signaling in liver cancer cells. J Ethnopharmacol 2011;136:197-203.

4. França AV, Elias Junior J, Lima BL, et al. Diagnosis, staging and treatment of hepatocellular carcinoma. Braz J Med Biol Res 2004;37:1689-705.
5. Chen M, Song F, Guo M, et al. Analysis of flavonoid constituents from leaves of Acanthopanax senticosus harms by electrospray tandem mass spectrometry. Rapid Commun Mass Spectrom 2002;16:264-71.

6. Li N, Lee HS, Zhang N, et al. Two new diphenyl ethers from Acanthopanax senticosus (Rupr. \& Maxim.) Harms with PTP1B inhibitory activity. Phytochem Lett 2015;13:286-9.

7. Nan JX, Park EJ, Nam JB, et al. Effect of Acanthopanax koreanum Nakai (Araliaceae) on D-galactosamine and lipopolysaccharide-induced fulminant hepatitis. J Ethnopharmacol 2004;92:71-7.

8. Ryu J, Son D, Kang J, et al. A benzenoid from the stem of Acanthopanax senticosus. Arch Pharm Res 2004;27:912-4.

9. Wang H, Sun B, Zhang Z, et al. Effects of Acanthopanax senticosus polysaccharide on the proliferation, apoptosis and cell cycle in human HepG2 cells. Pharmazie 2016; $71: 201-4$

10. Wang Q, Wang Y, Liu R, et al. Comparison of the effects of Mylabris and Acanthopanax senticosus on promising cancer marker polyamines in plasma of a Hepatoma-22 mouse model using HPLC-ESI-MS. Biomed Chromatogr 2013;27:208-15.

Okamoto T, Sanda T, Asamitsu K. NF-kappa B signaling and carcinogenesis. Curr Pharm Des 2007;13:447-62.

12. Baldwin AS. Control of oncogenesis and cancer therapy resistance by the transcription factor NF- $\mathrm{\kappa B}$. J Clin Invest 2001;107:241-6.

13. Pande V, Ramos MJ. NF- $\mathrm{kB}$ in human disease: current inhibitors and prospects for de novo structure based design of inhibitors. Curr Med Chem 2005;12:357-74.

14. Lee SC, Sim N, Clement MV, et al. Dominant negative Rac1 attenuates paclitaxel-induced apoptosis in human melanoma cells through upregulation of heat shock protein 27: A functional proteomic analysis. Proteomics 2007;7:4112-22.

15. Liu N, Yang HL, Wang P, et al. Functional proteomic analysis revels that the ethanol extract of Annona muricata L. induces liver cancer cell apoptosis through endoplasmic reticulum stress pathway. J Ethnopharmacol 2016;189:210-7.

16. Franken NA, Rodermond HM, Stap J, et al. Clonogenic assay of cells in vitro. Nature Protocols 2006;1:2315-9.

17. Li N, Tuo ZD, Xing SS, et al. A New Dammaranetype Triterpene with PTP1B Inhibitory Activity from Gynostemma pentaphyllum. Bull Korean Chem Soc 2014;35:3122-4.

18. Li N, Sun YN, Zhang L, et al. NF-kB inhibitory activities 
of triterpenoid glycosides from the stems of Acanthopanax senticosus (Rupr. \& Maxim.) Harms. Phytochem Lett 2016;15:210-4.

19. Bhanot A, Sharma R, Noolvi MN. Natural sources as potential anti-cancer agents: a review. Int J Phytomed 2011;3:9-26.

20. Newman DJ, Cragg GM. Natural products as sources of new drugs over the 30 years from 1981 to 2010. J Nat Prod 2012;75:311-35.

21. Said AH, Raufman JP, Xie G. The role of matrix metalloproteinases in colorectal cancer. Cancers (Basel) 2014;6:366-75.

Cite this article as: Zhao B, Zhu W, Han X, Li X, Lu Y, Cao X, Zhang F, Lin X, Zhang X, Chen Q. Ethanol extract of Acanthopanax senticosus (Rupr. \& Maxim.) Harms induces liver cancer cell apoptosis through inhibiting NF- $\kappa \mathrm{B}$. Transl Cancer Res 2020;9(2):1032-1043. doi: 10.21037/tcr.2020.01.02
22. Sultana A, Idress R, Naqvi ZA, et al. Expression of the Androgen Receptor, pAkt, and pPTEN in Breast Cancer and Their Potential in Prognostication. Transl Oncol 2014. [Epub ahead of print].

23. Shen F, Cai WS, Li JL, et al. Synergism from the combination of ulinastatin and curcumin offers greater inhibition against colorectal cancer liver metastases via modulating matrix metalloproteinase- 9 and E-cadherin expression. Onco Targets Ther 2014;7:305-14.

24. Chen Y, Takizawa N, Crowley JL, et al. F-actin and myosin II binding domains in supervillin. J Biol Chem 2003;278:46094-106.

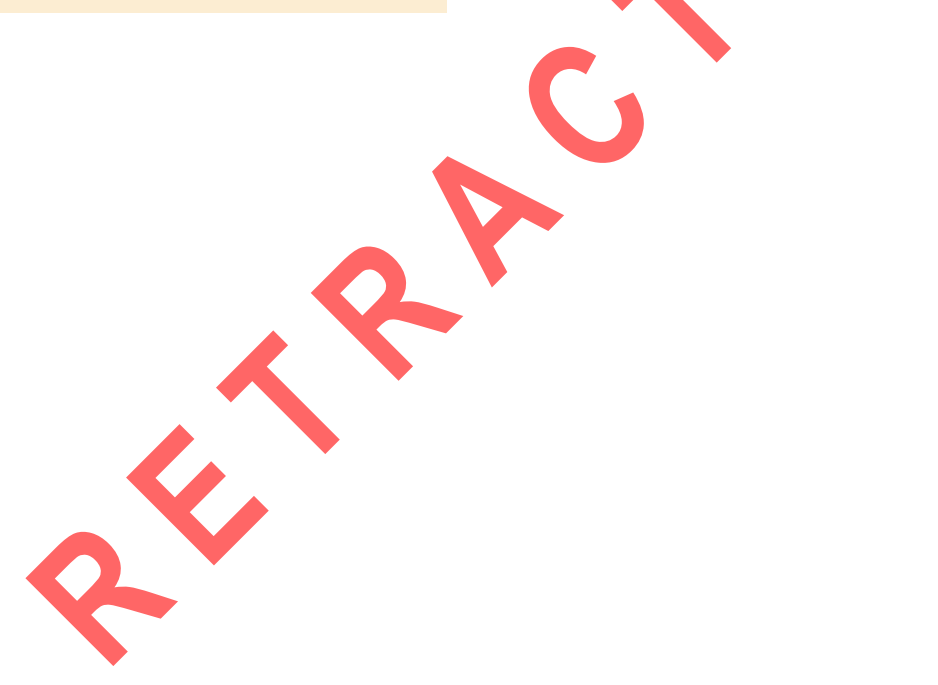




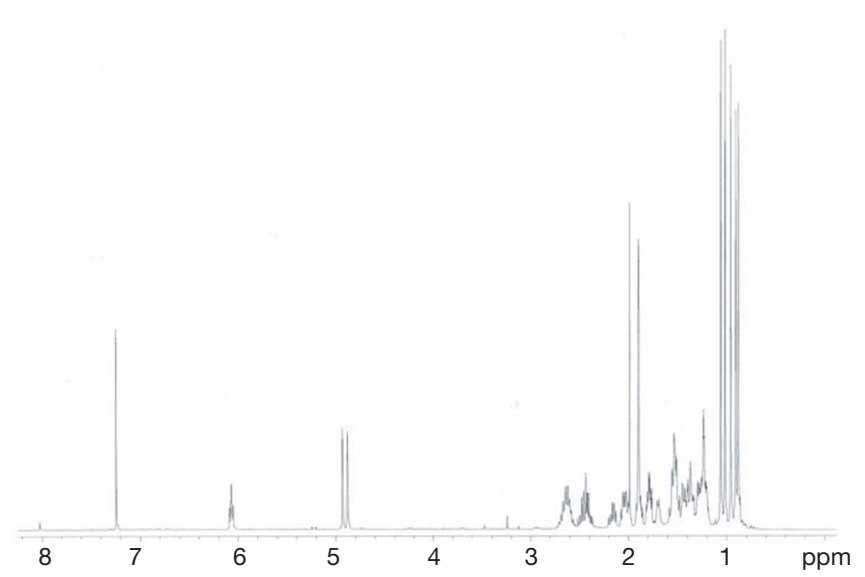

Figure S1 ${ }^{1} \mathrm{H}-\mathrm{NMR}$ spectrum of compound $1\left(\mathrm{CDCl}_{3}, 500 \mathrm{MHz}\right)$.

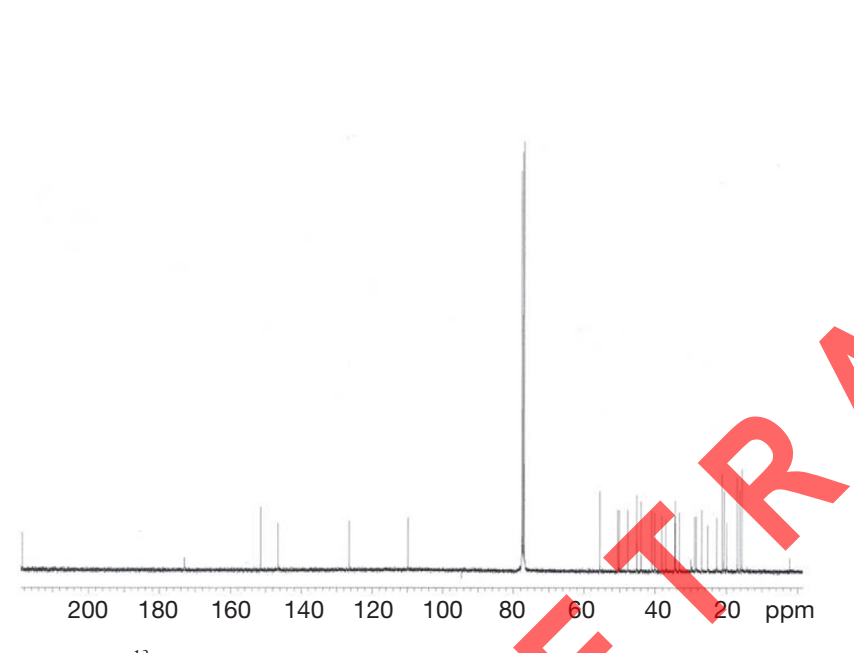

Figure S2 ${ }^{13} \mathrm{C}-\mathrm{NMR}$ spectrum of compound $1\left(\mathrm{CDCl}_{3}, 125 \mathrm{MHz}\right)$.

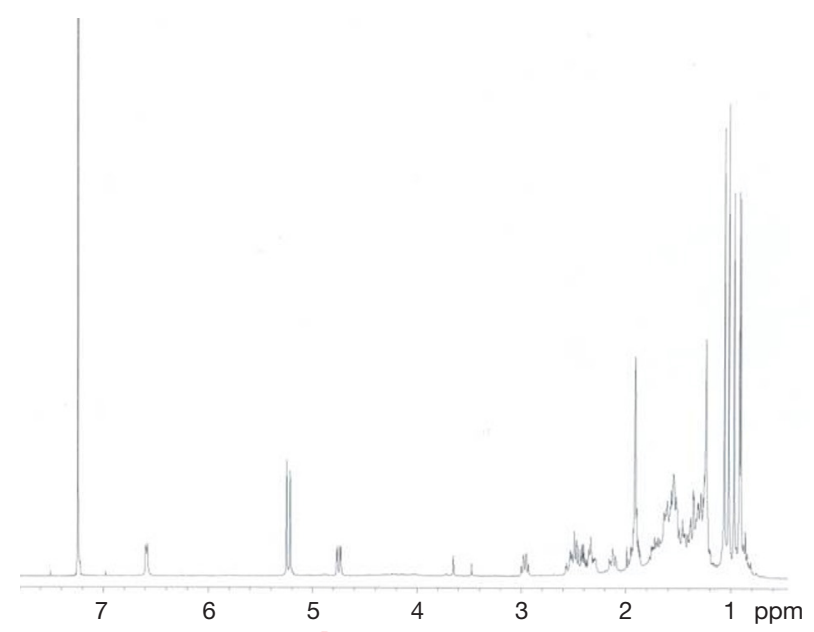

Figure S3 ${ }^{1} \mathrm{H}-\mathrm{NMR}$ spectrum of compound $2\left(\mathrm{CDCl}_{3}, 500 \mathrm{MHz}\right)$.

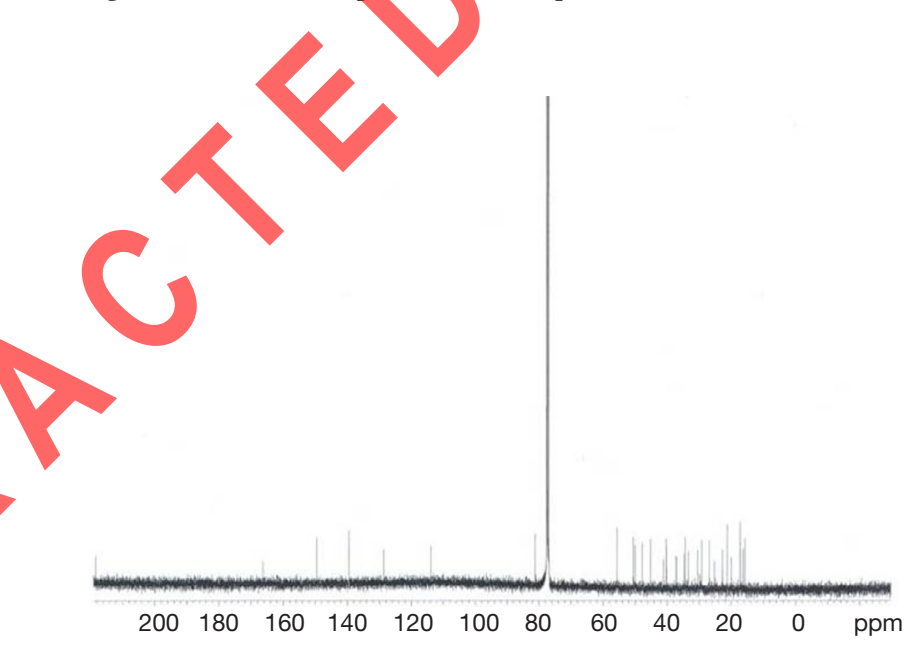

Figure $\mathrm{S} 4{ }^{13} \mathrm{C}-\mathrm{NMR}$ spectrum of compound $2\left(\mathrm{CDCl}_{3}, 125 \mathrm{MHz}\right)$. 


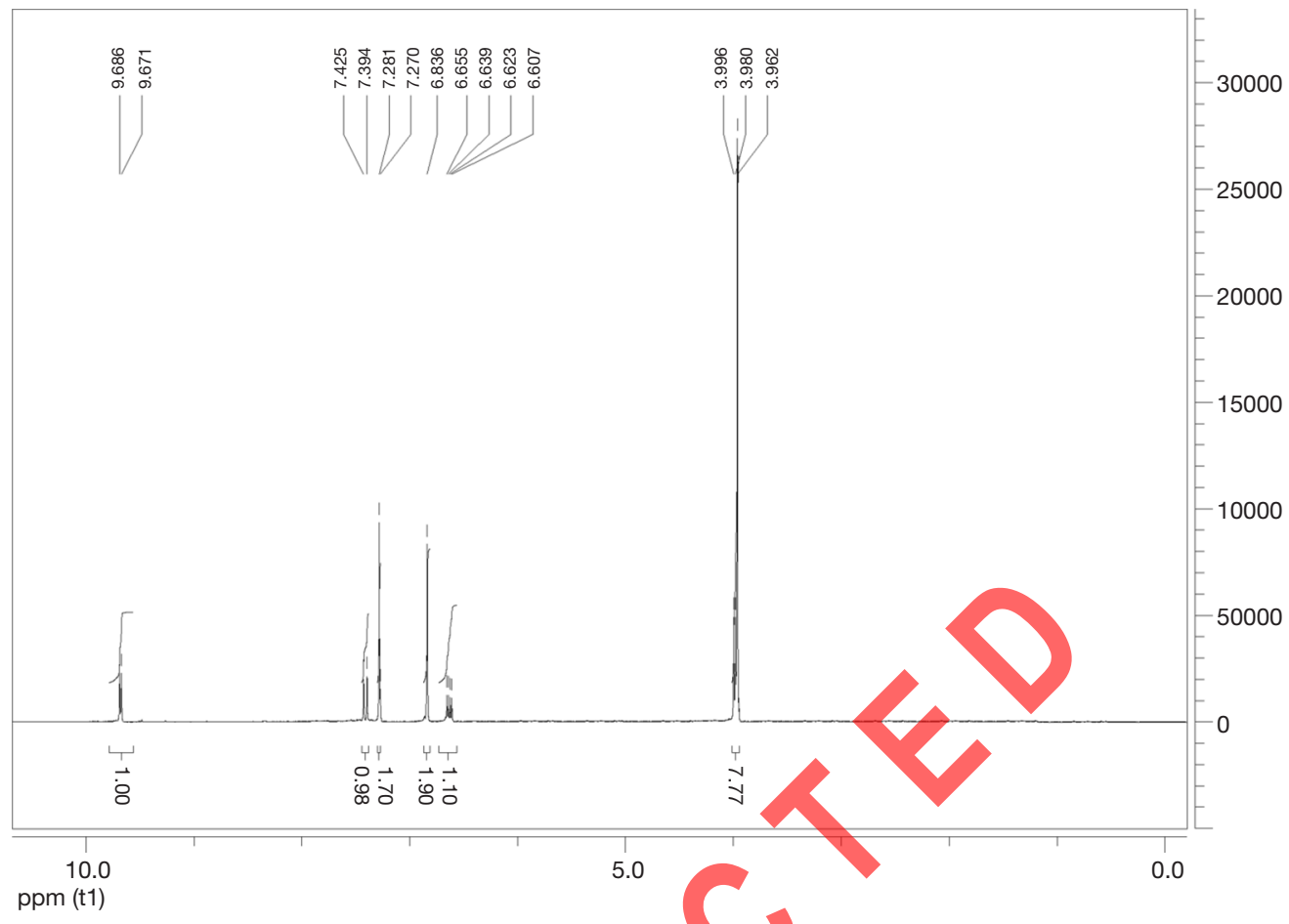

Figure $\mathbf{S} 5{ }^{1} \mathrm{H}-\mathrm{NMR}$ spectrum of compound $3\left(\mathrm{CDCl}_{3}, 500 \mathrm{MHz}\right)$.

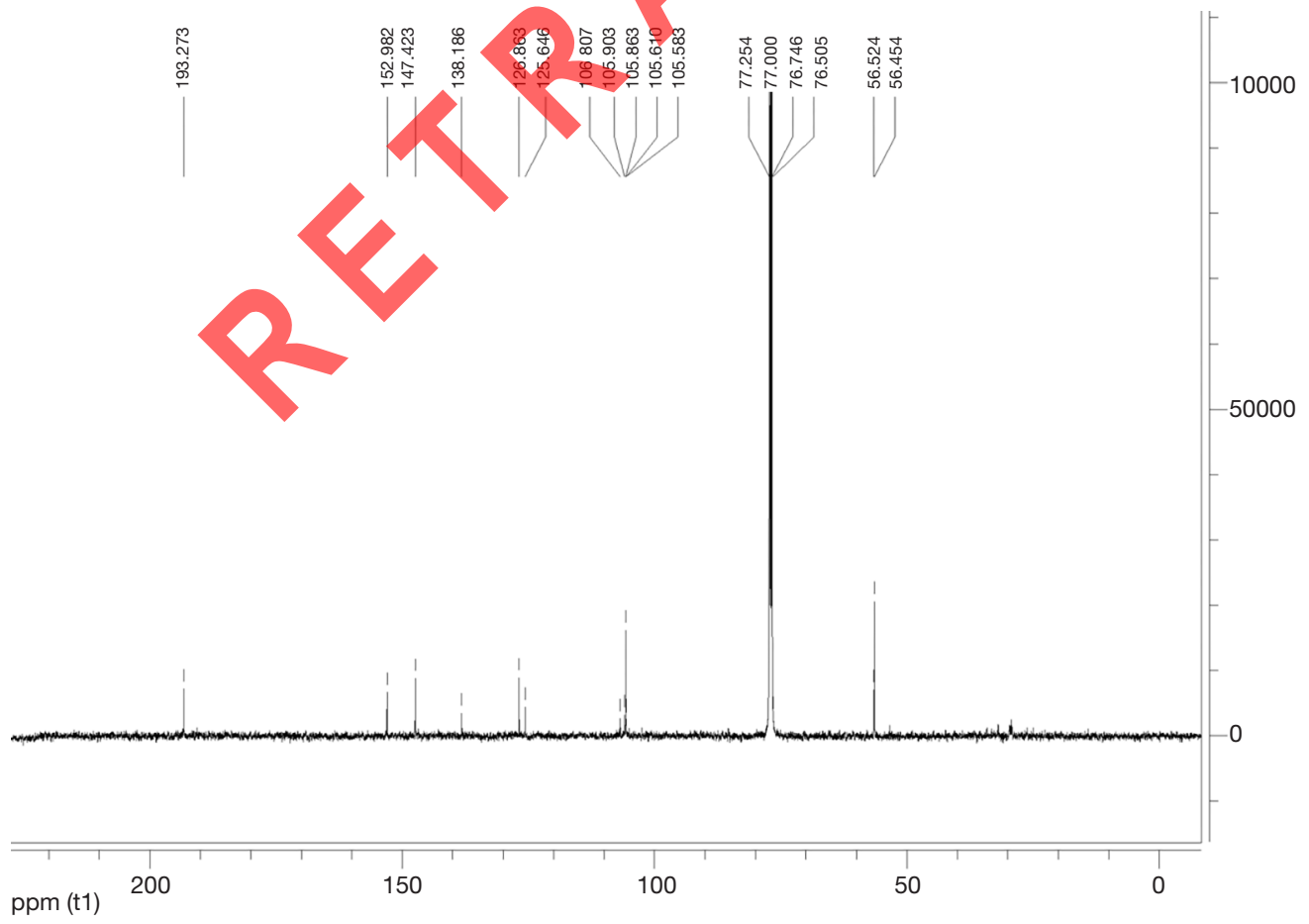

Figure $\mathbf{S 6}{ }^{13} \mathrm{C}-\mathrm{NMRspectrum}$ of compound $3\left(\mathrm{CDCl}_{3}, 125 \mathrm{MHz}\right)$. 


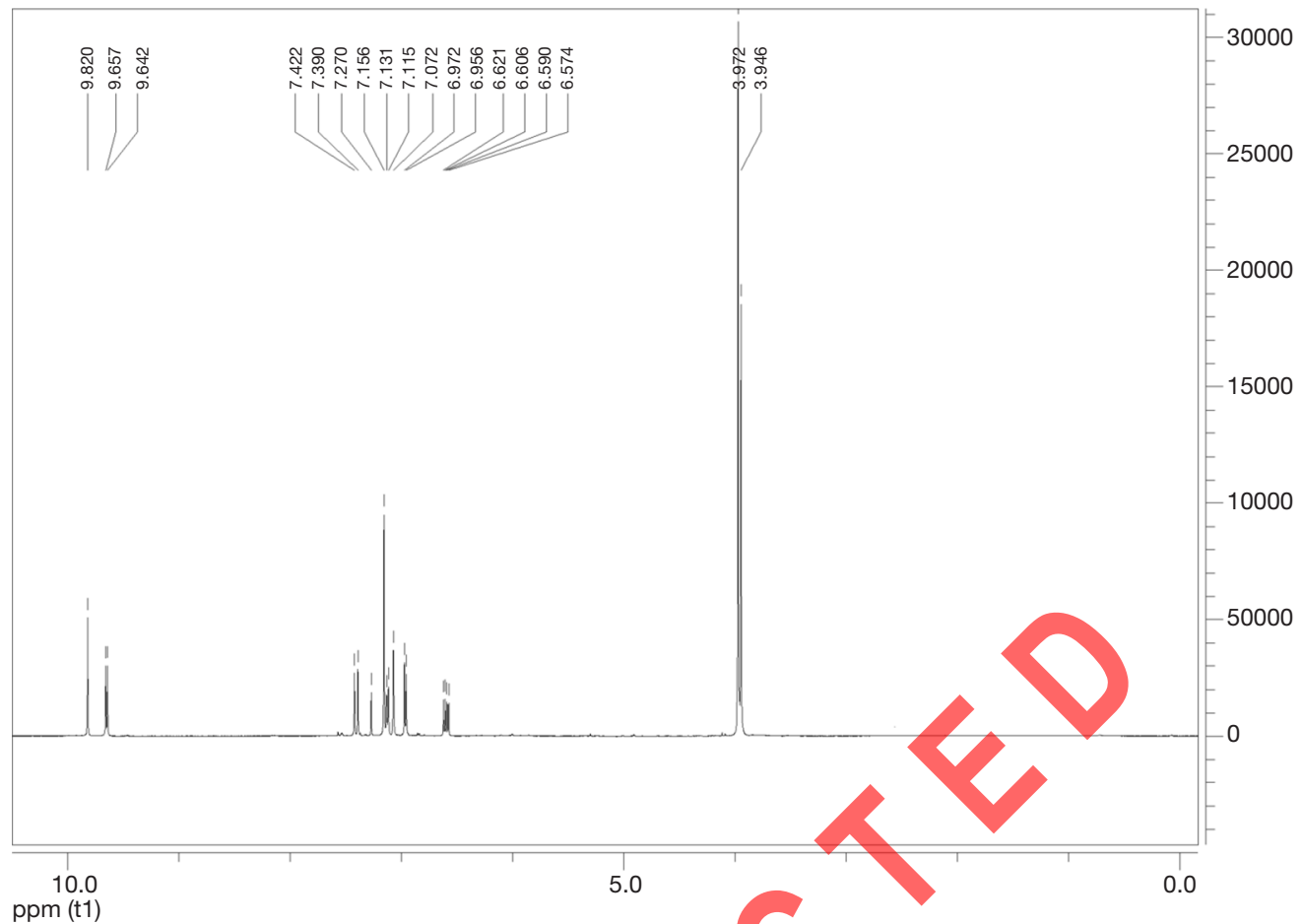

Figure $\mathbf{S} 7{ }^{1} \mathrm{H}-\mathrm{NMR}$ spectrum of compound $4\left(\mathrm{CDCl}_{3}, 500 \mathrm{MHz}\right)$.

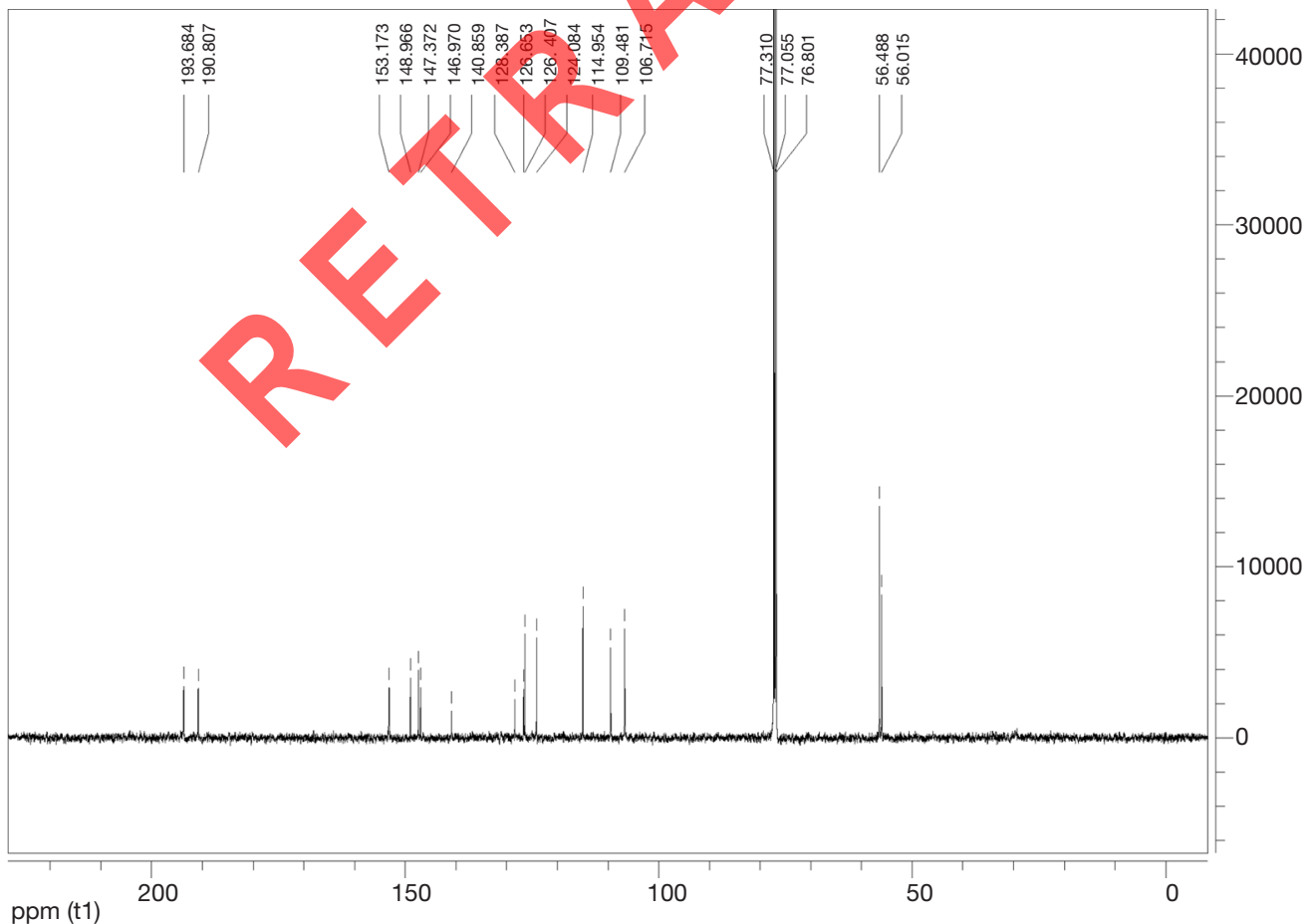

Figure S8 ${ }^{13} \mathrm{C}-\mathrm{NMR}$ spectrum of compound $4\left(\mathrm{CDCl}_{3}, 125 \mathrm{MHz}\right)$. 


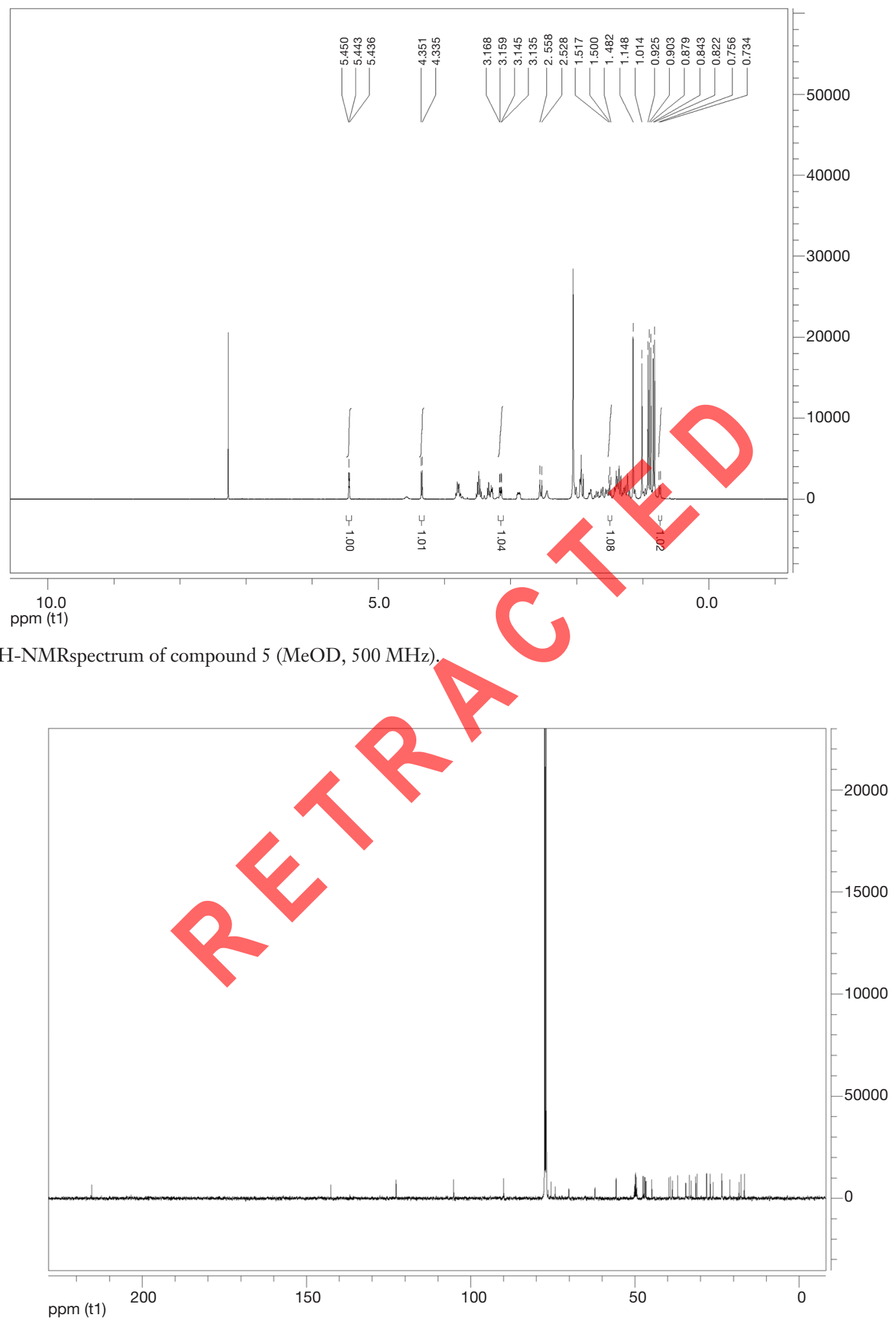

Figure $\mathbf{S 1 0}{ }^{13} \mathrm{C}-\mathrm{NMR}$ spectrum of compound 5 (MeOD, $125 \mathrm{MHz}$ ). 


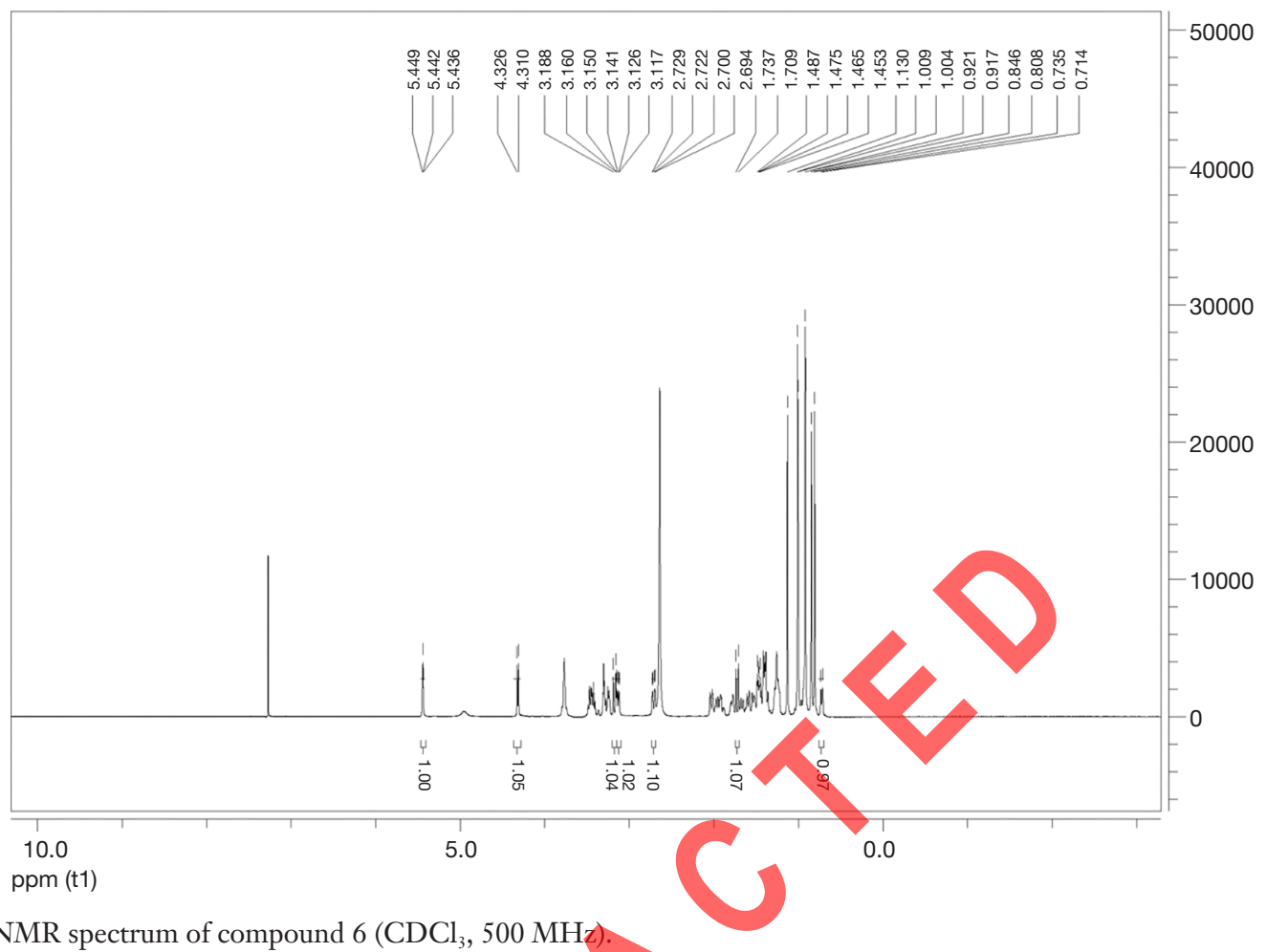

Figure $\mathbf{S 1 1}{ }^{1} \mathrm{H}-\mathrm{NMR}$ spectrum of compound $6\left(\mathrm{CDCl}_{3}, 500 \mathrm{MHz}\right)$.

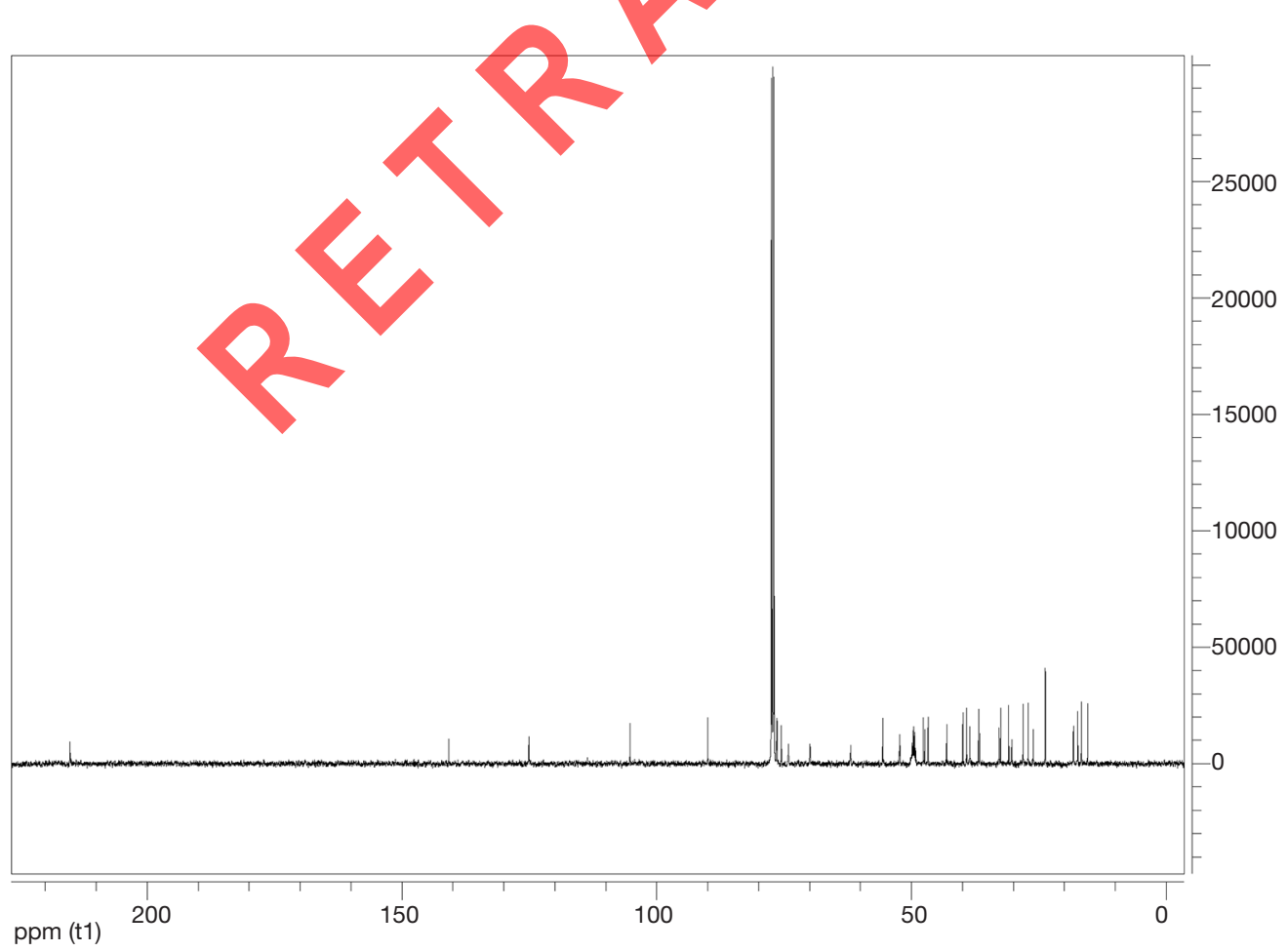

Figure S12 ${ }^{13} \mathrm{C}-\mathrm{NMR}$ spectrum of compound $6\left(\mathrm{CDCl}_{3}, 125 \mathrm{MHz}\right)$. 


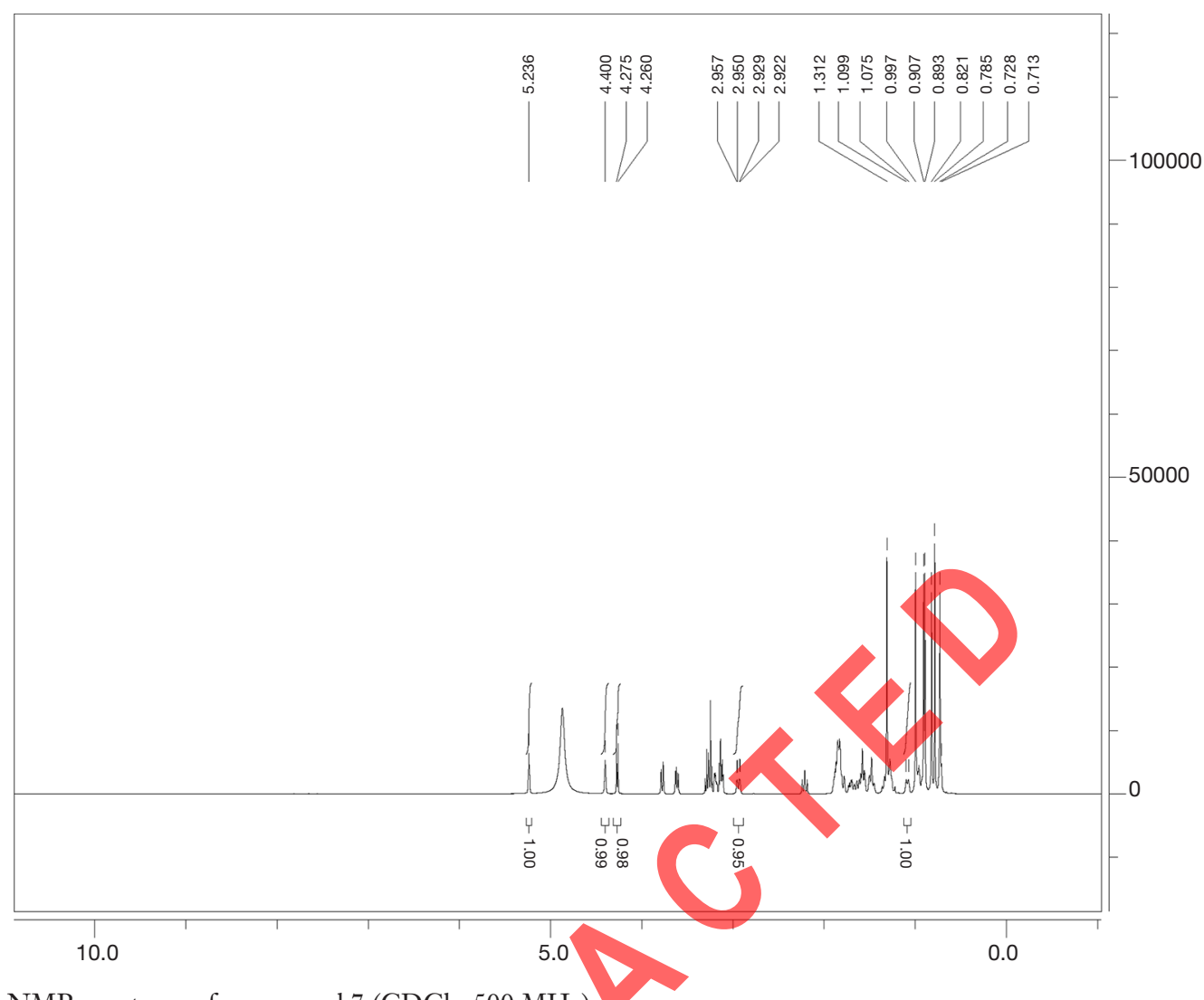

Figure $\mathbf{S 1 3}{ }^{1} \mathrm{H}-\mathrm{NMR}$ spectrum of compound $7\left(\mathrm{CDCl}_{3}, 500 \mathrm{MHz}\right)$.

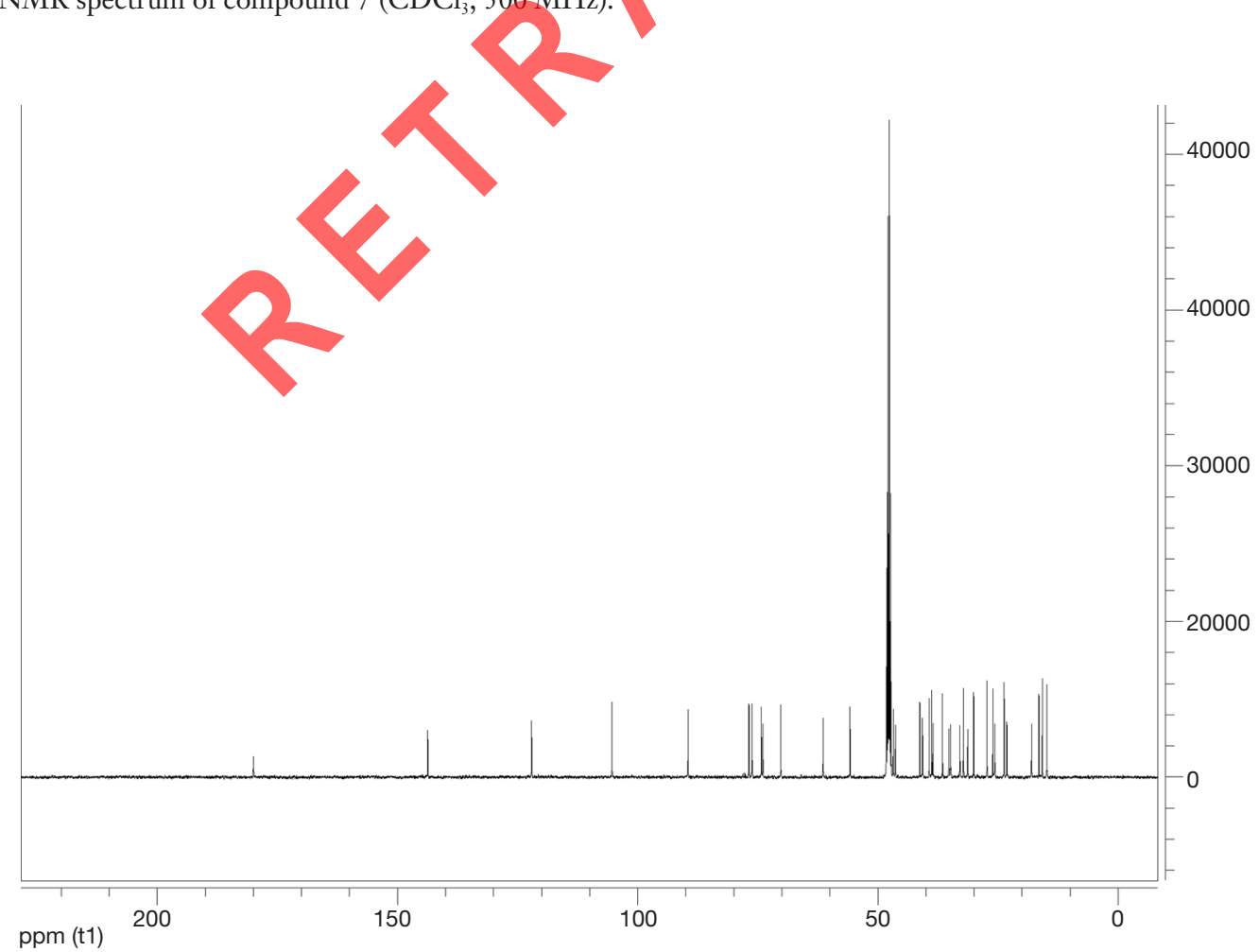

Figure S14 ${ }^{13} \mathrm{C}-\mathrm{NMR}$ spectrum of compound $7\left(\mathrm{CDCl}_{3}, 125 \mathrm{MHz}\right)$. 